\title{
Espejos de tinta Nuevas aproximaciones a los usos del escrito en Cervantes*
}

\author{
Antonio Castillo Gómez**
}

Leer el Quijote hoy es una tarea casi imposible. Quiero decir, no puede leerse el Quijote como un libro virgen, cuyas páginas nunca hemos abierto.

MANGUel (2005: 49).

\section{LA VOZ Y EL TEXTO}

Entre el rótulo «Aquí se imprimen libros», que saluda la visita de don Quijote y Sancho a la imprenta barcelonesa donde a la postre se estaba corrigiendo un pliego de Luz del alma - referencia tal vez al catecismo de fray Felipe Meneses (1554) o más probablemente a un título ideal para designar tal género libresco (Rico 2002a: 699) - y otro de la Segunda parte del ingenioso hidalgo don Quijote de la Mancha, compuesta por un «vecino de Tordesillas» - a la sazón el apócrifo de Avellaneda (II, LXII) — y la caracterización que se hace de Sancho como una persona incapaz de «decir razón sin refrán, ni refrán que no me parezca razón», cuando el escudero responde así a la reprimenda de

* La redacción final de este trabajo se inscribe en el marco del proyecto de investigación Cinco siglos de cartas. Escritura privada y comunicación epistolar en la Edad Moderna y Contemporánea, financiado por el Ministerio de Ciencia e Innovación (HAR2008-00874-HIST); en tanto que el primer esbozo, con el título «Escritura y oralidad en torno a Cervantes» lo presenté en el Seminario internacional Los textos de Cervantes, dirigido por Francisco Rico, organizado por el Centro para la Edición de los Clásicos Españoles (CECE) y la Biblioteca Nacional de España, celebrado en los ya lejanos 17-19 de diciembre de 2005.

** Universidad de Alcalá. SIECE. Grupo LEA. 
su señor por hablar ensartando refranes y consejas (II, LXXI: 1316) ${ }^{1}$, median numerosas citas y pasajes que traen al primer término el escenario de las tecnologías de la comunicación en la España de Cervantes ${ }^{2}$. Sumando dichas referencias a las abundantes apreciaciones sobre estilos, géneros y asuntos literarios que se deslizan en el Quijote, y en varias obras más, no es mucho desatino concluir que una faceta propia del autor fue su inclinación a convertir en materia narrativa los problemas de la literatura, incluidos los aspectos técnicos (Jauralde Pou 1995: 144). Su mirada, sin embargo, no se detuvo tan sólo en esos negocios que fueron comidilla más que habitual del gremio de las gentes de letras, sino que, en general, recorrió el ancho mundo de la escritura, en lo que tal vez pueden atisbarse reflejos directos de los menesteres burocráticos en los que anduvo empleado Cervantes (Dopico Black 2005: 29) ${ }^{3}$.

Naturalmente, por más que atendamos a sus significados y usos en la sociedad áurea, la cultura del Barroco no se puede entender orillando el rol desempeñado por las tecnologías oral y visual a la hora de transmitir y constituir la información, el saber y la memoria. Aunque durante un cierto tiempo la dedicación puesta en rescatar los espacios de lo escrito puede haber generado una cierta postergación de las realidades cubiertas por las palabras y las imágenes, es evidente que éstas eran intrínsecas a aquella realidad cultural (Chartier 2005a). A guisa de recordatorio valdrá con evocar su indiscutible protagonismo en manifestaciones tan genuinamente barrocas como la predicación y el teatro.

El arte del sermón - cuya sombra quijotesca se percibe en algunos de los discursos pronunciados por el hidalgo manchego (Garau 2001), ya fuera el que se ocupó de la edad de oro (I, XI), el que mostró el combate entre las armas y las letras (I, XXXVII-XXXVIII) o ese otro sobre la paz y la guerra (II, XXVII) - requería de una preparación previa confiada a la lectura y a la escritura. Luego venía el momento de pronunciarlo y entonces las anotaciones pasaban a ocupar un segundo lugar ante la expresividad verbal, gestual $\mathrm{y}$, en suma, visual del predicador, según se encargaba de recordar la retórica sagrada. En cuanto al teatro, aquí, sin duda, la representación era todavía más trascendental, confiada a la capacidad de los comediantes para decir el verso

1. En las citas del Quijote sigo la edición de Francisco Rico para el Instituto Cervantes (Cervantes 2005).

2. A ellas se refirió tiempo atrás Iffland (1989) y últimamente Paz Gago (2005). Si se trata de revisar las formas de comunicación en la Edad Moderna están la visión general de Peter Burke en Briggs-Burke (2002) y la específica española de Fernando Bouza (1999a). Distintas miradas a los usos y senderos de la escritura, el libro y la lectura en la época, con especial atención a las alusiones cervantinas, pueden hallarse en Marchant Rivera (2003), Bouza (2004) y Galende Díaz (2005), más los volúmenes colectivos compilados por Castillo Gómez (1999a), Menéndez Peláez (2005) y Lucía Megías (2006a), donde se incluye también una amplia bibliografía sobre la imprenta y el mundo de libro (Alcantarilla y Lucía Megías 2006). Si lo que se busca es un acercamiento global a la cultura y a la época bien se puede comenzar por Javier Zamora (1986) y seguir por algunas de las obras publicadas al abrigo del cuarto centenario del Quijote, en particular Feros y Gelabert (2004), Iglesias (2005) y Rivero Rodríguez (2005). En cuanto a las relaciones entre Barcelona, Cervantes y la obra de éste, Riquer (2003: 283-385) y Riera (2005).

3. Aprovecho para indicar que en este texto doy continuidad a otras reflexiones anteriores sobre las huellas de la cultura escrita en la obra de Cervantes: Castillo Gómez (2001b y 2004). 
y darle vida acoplándolo a los diferentes públicos, pues no era lo mismo actuar ante espectadores cortesanos que hacerlo en los más populares corrales de comedias. No obstante, aunque pudiera pasar desapercibido, detrás había un texto susceptible de ser manipulado o reescrito en las sucesivas versiones del mismo o en las apuntaciones efectuadas por las compañías teatrales en el momento de llevarlo a escena (Chartier 1999 y 2002a, y Profeti 1999).

La palabra hablada daba vida a una comunicación necesariamente presencial en tanto que los escritos y las imágenes, máxime con el favor de la imprenta, hacían factible la posibilidad de sostenerla en la distancia y de reproducirla en sucesivos momentos como registros de lo acontecido. Es lo que vino señalar el portugués Diogo Henriques de Vilhegas en su Leer sin libro. Direcciones acertadas para el gobierno éthico, económico y político (Lisboa, 1672). Tras admitir que voces, imágenes y letras constituían otros tantos modos de significar «la cosa mesma y también el mismo concepto», agregó que con las palabras sólo se podía «comunicar a los que asisten presentes los conceptos del ánimo»; mientras que los «caracteres, letras o figuras» servían «para declarar a los ausentes nuestros designios, pensamientos y afectos, o para introduzirnos en el conocimiento del tercero» (Bouza 1999a: 30-31).

En el contexto de la temprana Edad Moderna, ese debate cobró fuerza por la centralidad cultural de la escritura. Es cierto, como antes decía, que esta no se puede entender al margen de las voces y de las imágenes, como formas también de conocimiento y memoria, pero esto no es óbice para reconocer la nueva dimensión adquirida por ella en cualquiera de sus materializaciones. Huelga señalar que en la constitución del Estado Moderno se halla inscrita una mentalidad alfabético-burocrática que requería inexcusablemente del concurso administrativo y memorial de la escritura. Sin desmarcarnos mucho de los textos cervantinos es suficiente con recordar la recreación que algunas de estas piezas proporcionan al respecto, en particular todo cuanto afecta al desempeño de Sancho Panza como gobernador de Barataria. Recuérdese que, a poco de ser nombrado para tan alta y deseada responsabilidad, el escudero advirtió ya lo necesario y útil que era saber leer y escribir para regir la ínsula. Lo apunta en el preciso momento en que se ve incapaz de leer la inscripción con el registro casi notarial de su toma de posesión:

En tanto que el mayordomo decía esto a Sancho, estaba él mirando unas grandes y muchas letras que en la pared frontera de su silla estaban escritas, y como él no sabía leer, preguntó que qué eran aquellas pinturas que en aquella pared estaban. Fuele respondido:

- Señor, allí está escrito y notado el día en que vuestra señoría tomó posesión desta ínsula, y dice el epitafio: «Hoy día, a tantos de tal mes y tal año, tomó la posesión desta ínsula el señor Sancho Panza, que muchos años la goce» (II, XLV: 1083).

Abundando en la misma idea, algunas décadas más adelante, Baltasar Gracián se encargaría de recordar en la segunda parte de El criticón (1653), 
donde se daba término a la competición entre las Artes y las Ciencias por el título de Reina, que quien tuviera la intención de reinar debía antes conocer la escritura. Sancho, en efecto, lo primero que hizo tras acceder al gobierno de Barataria fue designar a quien iba a llevar las riendas papeleras de ese Estado que casi podemos estimar como la representación literaria de la burocratizada monarquía de los Austrias. En particular porque su falta ya no sólo le impedía leer el letrero puesto en su nombre sino también la correspondencia que empezaba a llegarle y a la que, claro está, debía ir dando respuesta:

- Correo viene del duque mi señor: algún despacho debe traer de importancia.

Entró el correo sudando y asustado, y, sacando un pliego del seno, le puso en las manos del gobernador, y Sancho le puso en las del mayordomo, a quien mandó leyese el sobrescrito, que decía así: A don Sancho Panza, gobernador de la insula Barataria, en su propia mano o en las de su secretario. Oyendo lo cual Sancho, dijo:

—¿Quién es aquí mi secretario?

$\mathrm{Y}$ uno de los que presentes estaban respondió:

- Yo señor, porque sé leer y escribir, y soy vizcaíno.

- Con esa añadidura — dijo Sancho- bien podéis ser secretario del mismo emperador. Abrid ese pliego y mirad lo que dice.

Hízolo así el recién nacido secretario y, habiendo leído lo que decía, dijo que era negocio para tratarle a solas. Mandó Sancho despejar la sala y que no quedasen en ella sino el mayordomo y el maestresala, y los demás y el médico se fueron; y luego el secretario leyó la carta, que así decía [...] (II, XLVII: 1100-1101).

Según apunte de Giuseppe Grilli (2004), las cartas que urden distintos pasajes de la historia cervantina tienen todo el aspecto de una «parodia posthumanista» del género epistolar debido a lo improbable y disparatado de muchas de las escenas donde se insertan. Pero que dichos fragmentos no sean enteramente verosímiles en cuanto al pormenor de su contenido y al orden preceptuado no anula su valor testimonial. Dado que ni se puede obviar la libertad creadora del escritor ni poner cerco a la imaginación o hacer de la literatura un cándido plagio de la realidad, reducir nuestro nivel de lectura al grado de adecuación de las cartas cervantinas a la retórica epistolar supondría despreciar lo que tienen de expresión de una práctica social perfectamente documentada y difundida en los tiempos áureos. Desde esta perspectiva, no interesan tanto por su estricta adecuación a los modelos epistolares, tan en boga y en muchos puntos igualmente increíbles, sino porque iluminan sobre la importancia que tuvo entonces esta forma de comunicación, sin duda una de las más características del escribir cotidiano. Incluso aceptando lo inverosímil de las cartas cervantinas, en ellas puede apreciarse una clara distinción en el tono epistolar según quien las escribiera, o mandara escribir, o según la condición del destinatario. Así en las de Teresa Panza a la Duquesa domina siempre el tratamiento de usted como signo de deferencia; mientras que 
cuando escribe a Sancho adopta un carácter más próximo y coloquial. En las cartas de este cariz se alcanza, a veces, un punto hilarante que desdecía el buen escribir recomendado en los tratados, siempre discreto y exento de cualquier muestra de afectación.

Como se sabe, tamaña circulación de cartas desembocó en la publicación de numerosos manuales y formularios destinados a enseñar el modo de escribirlas, su retórica, la disposición de los espacios, el valor de los blancos, los sobrescritos o el correcto empleo de los tratamientos y expresiones de cortesía. Es decir, todo cuanto hacía de las cartas un espejo de quienes las escribían y un signo de deferencia hacia el destinatario (Castillo Gómez 2005b). Observar dichas normas era una manera de mostrar el respeto y la adhesión al contrato social establecido en cada acto de escritura, mayor cuanto más lo fuera la formalidad de éste. Había que acomodar el discurso a la condición y calidad de la persona a la que iban dirigidas dado que, conforme propuso Antonio de Torquemada en su Manual de escribientes (ca. 1552), «los que escriben cartas, las han de saber variar y mudar en diversas maneras, como se mudan el pulpo y el camaleón» (Torquemada 1994: 135) ${ }^{4}$.

\section{ORALIDAD, TEXTO Y RECEPCIÓN}

«A la llana, con palabras significantes», así define Cervantes lo más característico de su estilo literario. El autor, al decir de Francisco Rico (2002: 146), no se vale del lenguaje convencional a la literatura sino que opta por uno más enraizado en lo cotidiano y doméstico. Bajtín habló en su día de la «polifonía lingüística» para designar la variedad de registros propia de cada momento de la lengua, que en el Quijote podemos apreciar por los juegos y confrontaciones de niveles que se suceden en el texto, oscilando siempre entre la vertiente más retórica y libresca de los personajes inmersos en el mundo de la escritura, con el hidalgo a la cabeza, y los tonos más coloquiales de aquéllos arraigados en el mundo oral de la gente común (Sacido 1995-1997). Sancho sería así la encarnación del habla ruda y llana, mientras que don Quijote se mueve entre el lenguaje caballeresco y anticuado que emplea cuando ejerce de tal o el más elegante y discreto que usa en otras situaciones. Esta variedad y modulación de registros, o sociolectos, según quien habla y cuando lo hace, expresa la proximidad de una obra en la que, como anotó Lázaro Carreter (2005: XXV), «al introducir la verdad de la calle y de los caminos, penetra en el relato la verdad del idioma».

Ahí pudo radicar una de las razones que justificaron su relativo éxito y la pronta difusión de la obra en formatos y soportes diversos. Otra, por

4. Sobre este texto, Rodríguez Cacho (1988) y Gimeno Blay (1999). Sobre los tratados y usos epistolares del Siglo de Oro pueden verse mis trabajos (2000b, $2003 b$ y 2006b: 19-57), así como Pontón (2002), Martín Baños (2005), los artículos recogidos en Bouza (2005a) y Serrano Sánchez (2008). 
supuesto, tuvo que ver con la sabía elección y caracterización de los personajes. Cervantes se valió del conocido recurso a la pareja de protagonistas, el hidalgo y su escudero, acentuando los rasgos cómicos, de manera que pudiera emparentarse con otros dúos ya inscritos en el imaginario colectivo. Diversos estudios de la obra han incidido, por un lado, en la trascendencia de lo burlesco y festivo en su composición; y, por otro, en el parentesco de don Quijote y Sancho con don Carnal y doña Cuaresma, en general, y, en particular, con un dúo de cómicos italianos muy célebres en la España de finales del siglo XVI: Ganassa y Bottarda, uno delgado y el otro gordo, como don Quijote y Sancho (Riley 2001: 175).

La comicidad de los personajes cervantinos se hizo visible en distintos festejos casi contemporáneamente a la publicación de la primera parte de la novela. Según refiere Pinheiro da Veiga en su Fastiginia, el mismo 1605 ya se les vio intervenir en las fiestas de toros y cañas que se convocaron en la capital castellana para celebrar el nacimiento del futuro Felipe IV. Dos años después, las efigies de don Quijote, Sancho, el cura, el barbero y la princesa Micomicona desfilaron en los fastos organizados en la ciudad de Pausa por el nombramiento del marqués de Montesclaros como nuevo Virrey del Perú. En 1613 el hidalgo tomó parte en el recibimiento que Heidelberg dispensó a Federico V, elector del Palatinado, y a su esposa Isabel de Estuardo. Al año siguiente se le vio por las calles de Zaragoza integrando la mascarada montada por los estudiantes durante las fiestas por la beatificación de Santa Teresa; el mismo motivo que le valió otro paseo por Córdoba en 1615. Entre 1617 y 1618 participó en las celebraciones convocadas en Sevilla, Baeza, Salamanca y Utrera para honrar la publicación del misterio de la Inmaculada Concepción. Y, en fin, en 1621 la figura de don Quijote asomaba entre las máscaras preparadas por el gremio de los plateros de México en honor de la beatificación de San Isidro ${ }^{5}$.

Mucho se ha escrito sobre la dialéctica oralidad y escritura en el Quijote, por lo que no parece oportuno insistir más en ello salvo atendiendo a otros aspectos que no sean solamente los internos a la composición de la obra. Amén del lenguaje aditivo, la ascendencia oral del texto puede atisbarse en algunos de los elementos que sostienen la estructura literaria ${ }^{6}$. Es el caso de la importancia atribuida a los diálogos en el discurrir narrativo; la constante intercalación de historia y relatos, unos más integrados en la trama central y otros más secundarios; las continuas transiciones del estilo indirecto al directo o viceversa; la habilidad cervantina para apelar frecuentemente al lector con objeto de que éste se sienta cómplice de la novela y hasta casi un personaje

5. De todo ello puede hallarse noticia más amplia en Riley (2001), Lobato (1992), Montero Reguera (1992 y 2006a: 319-322), López de Mariscal y Farré (2004: 31-33). Lucía Megías y Vargas (2005) publicaron años atrás una nueva edición con facsímil incluido de la Relación de las fiestas que se celebraron en la corte de Pausa, dada a conocer hace tiempo por Rodríguez Marín (1911).

6. Este tema ha reclamado la atención, por lo menos, de Moner (1989), Sacido Romero (19951997), Frenk (1997 y 2004), Martín Morán (1997a, 1997b y 2008), Paz Gago (1998: 1169-1179), Viñao Frago (2004) y Martínez Mata (2008). 
de la misma; y, por supuesto, su división en capítulos breves susceptibles de encadenar momentos de lectura sustanciados por las fórmulas introducidas para garantizar el suspense y preservar la expectación. Este último rasgo ha sido invocado en distintos ensayos para sugerir la lectura en alta voz como una de las modalidades de apropiación del Quijote (Chartier 1997: 30-31; López de Mariscal y Farré 2004: 27), admitida, por cierto, por el autor respecto al apócrifo de Avellaneda, aunque también fuera porque eso le venía como anillo al dedo para justificar el porqué de la segunda parte:

Llegase, pues, la hora del cenar, recógese a su estancia don Quijote, trujo el huésped la olla, así como estaba, y sentase a cenar muy de propósito. Parece ser que en otro aposento que junto al de don Quijote estaba, que no le dividía más que un sutil tabique, oyó decir don Quijote:

- Por vida de vuestra merced, señor don Jerónimo, que en tanto que traen la cena leamos otro capítulo de la segunda parte de Don Quijote de la Mancha.

-Apenas oyó su nombre don Quijote, cuando se puso en pie y con oído alerto escuchó lo que dél trataban y oyó que el tal don Jerónimo referido respondió:

- ¿Para qué quiere vuestra merced, señor don Juan, que leamos estos disparates, si el que hubiere leído la primera parte de la historia de don Quijote de la Mancha no es posible que pueda tener gusto en leer esta segunda?

- Con todo eso — dijo el don Juan-, será bien leerla, pues no hay libro tan malo, que no tenga alguna cosa buena. Lo que a mí en este más desplace es que pinta a don Quijote ya desenamorada de Dulcinea del Toboso (II, LIX: 1213).

Esta lectura en alta voz seguramente no sería tanto «espectáculo declamatorio al modo juglaresco», cuanto una de esas reuniones que servían de marco para las lecturas caballerescas en la venta de Palomeque (Martín Morán 1997a: 123). La brevedad facilitaría una recepción segmentada que no debía fatigar a los lectores, sobre todo a los menos familiarizados con lo escrito, y que al mismo tiempo, en opinión de Roger Chartier, fuera percibida como autónoma y cerrada:

Muchas obras antiguas, desde las más fundamentales, como Don Quijote, están organizadas en capítulos cortos, perfectamente adaptados a las necesidades del performance oral que supone, por un lado, una duración limitada para no cansar al auditorio y, por otro, la imposibilidad para que los oyentes memoricen una intriga demasiado compleja. Los capítulos breves, que son unidades textuales, pueden así ser pensados como unidades de lectura cerradas en sí mismas y autónomas (Chartier 1997: 31).

Guiños, en suma, a una práctica lectora que podía desarrollarse en público y que permitiría establecer conexiones entre unas y otras narraciones con objeto de no perder el sentido general de la historia. Así, las sucesivas apariciones de 
los mismos personajes o la recurrencia de algunos de los episodios y situaciones narrados vendrían a mostrar el talento desplegado por Cervantes para retener a los lectores y conseguir que escucharan tan embobados como algunos de los oyentes evocados en distintos pasajes de la obra. Emplea, por ello, muchos elementos constitutivos de la literatura oral, como la concatenación que tanto exasperada al hidalgo cada vez que Sancho se disponía a contar un cuento:

— «Digo, pues prosiguió Sancho_- que en un lugar de Extremadura había un pastor cabrerizo, quiero decir que guardaba cabras, el cual pastor o cabrerizo, como digo de mi cuento, se llamaba Lope Ruiz; y este Lope Ruiz andaba enamorado de una pastora que se llamaba Torralba; la cual pastora llamada Torralba era hija de un ganadero rico; y este ganadero rico...».

- Si desa manera cuentas tu cuento, Sancho - dijo don Quijote-, repitiendo dos veces lo que vas diciendo no acabarás en dos días; dilo seguidamente y cuéntalo como hombre de entendimiento, y si no, no digas nada.

- De la misma manera que yo lo cuento — respondió Sancho- se cuentan en mi tierra todas las consejas, y yo no sé contarlo de otra, ni es bien que vuestra merced me pida que haga usos nuevos (I, XX: 232).

Ante la desaprobación de su señor, Sancho reclama la pertinencia de su modo de decir amparándose en la costumbre que había en su tierra y prosigue el relato presentándose como testigo de algunos de los hechos contados, como también era propio de las narraciones orales. Frente al valor probatorio de lo escrito argumentado en otros momentos, aquí se apela al testimonio personal. En don Quijote y Sancho se enfrentan dos tradiciones y dos mundos: una más apegada a la escritura y otra a la palabra viva.

\section{USOS DE LA MEMORIA}

Esta diferenciación de mundos y realidades que vemos incorporada en los personajes centrales del Quijote enlaza directamente con otro concepto central a la cultura del barroco: la memoria. En su Silva de varia lección (1540), el sevillano Pedro de Mexía distinguió entre la memoria frágil de los agudos de ingenio, «muy prestos en el tomar y flacos en el retener», y la más duradera de los rudos, quienes «con dificultad lo reciben y aprenden, pero sosténlo más» (Mexía 1989: 49; Chartier 2006: 43-44). A la hora de matizar o valorar las relaciones entre lo oral y lo escrito en cualquier sociedad, máxime si esta corresponde a un tiempo de tensión entre ambas tecnologías, procede pensar en los términos en que se materializa el empleo de una u otra. Cervantes, una vez más, expresa bien ese matiz cuando discurre sobre la escritura y la memoria en el entremés La elección de los alcaldes de Daganzo. En medio de la discusión que el bachiller y Algarroba sostienen respecto a las cualidades que debían reunir los aspirantes al oficio de alcalde, el segundo recuerda la 
proverbial memoria de Pedro de la Rana, conocedor de «todas las coplas, sin que letra falte» (Cervantes 2004b: 149). Aún más claro resulta cuando el bachiller le pregunta a Humillos si sabe leer y este le responde (pp. 154-155):

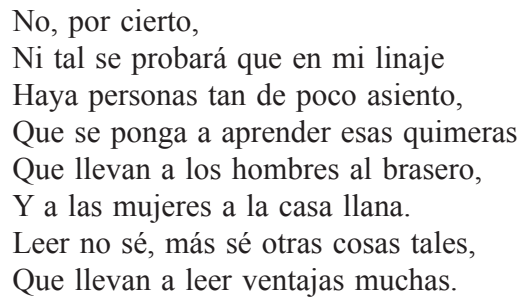

Interrogado por esos conocimientos que podían aventajar a la lectura, Humillos puntualiza:

\author{
Sé de memoria \\ Todas cuatro oraciones, y las rezo \\ Cada semana cuatro y cinco veces.
}

$\mathrm{Su}$ saber oral era común y afincado en una práctica reiterada del rezo, al igual que muchas otras gentes de la época. El cabrero Antonio cantaba «con muy buena gracia» el romance sobre sus amores compuesto por su tío el clérigo (Quijote I, XII: 144). Otros llegaron incluso a memorizar textos más extensos y difíciles, como los libros de caballerías que recitaba de cabeza el morisco Román Ramírez para deleite de distintas partidas de caballeros, entre ellas la que solía reunirse en la casa de don Antonio del Río. De él se dijo, por parte de algunos de los testigos llamados a declarar por el Santo Oficio de Cuenca, que antes de que supiese leer «sabía ya de memoria los más libros de cavallerías», siendo la razón de tan temprano aprendizaje que su padre «leía muy bien» y acostumbraba a hacerlo en su presencia, de manera que él «iba tomando en la memoria lo que le oía leer» ${ }^{7}$. De regreso al Quijote tal contraste es uno más de los aspectos que hacen opuestos y complementarios al hidalgo y a su escudero. Uno habla como si fuera un personaje sacado de los libros de caballería que lleva en su cabeza hasta tal punto que muchas veces no se le entiende. El otro lo hace según los usos habituales de la gente común y como éstos no sabe hacerlo si no es concatenando historias y salpicando el discurso con innúmeros refranes. Don Quijote representa al hombre libresco y, en consecuencia, interpreta el mundo conforme a lo que ha leído, aunque para ello tenga que acometer las empresas más desaforadas. Sancho, sin embargo, tiene sus raíces en la tierra y su conocimiento arranca de la sabiduría tradicional trasmitida por mediación de cuentos, proverbios y otra suerte de composiciones orales.

7. El expediente se conserva en el Archivo Diocesano de Cuenca, Inquisición de Cuenca, leg. 343, n. ${ }^{\circ} 4876$, «Proceso contra Román Ramírez, morisco, vezino y natural de la villa de Deça, 1595». El caso hace tiempo que mereció la atención de Ángel González Palencia (1929-1930) y posteriormente de Harvey (1975: 94-97). 
No obstante, la duplicidad de la memoria no está sólo en el uso de una u otra tecnología de conocimiento. Incluso valiéndose de la más estable de ellas, la escritura, también es posible señalar la diferencia radical entre una memoria efímera y otra de signo más permanente. Roger Chartier lo ha mostrado así en sus lecturas e interpretaciones del Quijote y singularmente de los pasajes referidos al «librillo de memoria» de Cardenio. Apoyándose en el Diccionario de Autoridades, que tuvo en Cervantes uno de los dos testimonios invocados para definir dicha entrada, sostiene que dicho objeto sería un librito formado por hojas embetunadas donde anotar todo cuanto no se quería fiar al albur de la memoria con el fin de borrarlo una vez cumplida su función (Chartier 2004a y 2006: 39-60). Se trataba de un producto gráfico de notable difusión en los círculos nobiliarios y en el teatro (Bouza 2003: 48-56; Gonzalo Sánchez-Molero 2004, II: 166-170), que en muchos aspectos podría considerarse como el homónimo español de las writing tables documentadas en Inglaterra, especialmente entre 1577 y 1628 (Stalybrass, Chartier, Mowery y Wolfe 2004; Woudhuysen 2004). Sin descartar que pudiera ser un soporte de esa naturaleza, otra posibilidad sería emparentarlo con la familia de los libros de cuentas, igualmente bien representados en los textos cervantinos (Castillo Gómez 2001b: 316-318 y 2006b: 61-79): ya sea el «librillo de memoria» en que Monipodio se hacía escribir y leer la contabilidad de los trabajos encomendados a su cuadrilla de maleantes; ese otro donde el ventero «asentaba la paja y la cebada que daba a los arrieros» (Quijote I, III: 65); o, en fin, el del padre de Dorotea. Como da a entender la alusión a este último, los apuntes consignados no lo eran para ser borrados de inmediato sino para conformar una memoria contable de mayor alcance susceptible de ser consultada y revisada cuando las circunstancias así lo requirieran:

\begin{abstract}
Y del mismo modo que yo era señora de sus ánimos, ansí lo era de su hacienda: por mí se recebían y despedían los criados; la razón y cuenta de lo que se sembraba y cogía pasaba por mi mano, los molinos de aceite, los lugares del vino, el número del ganado mayor y menor, el de las colmenas; finalmente, de todo aquello que un tan rico labrador como mi padre puede tener y tiene, tenía yo la cuenta y era la mayordoma y señora, con tanta solicitud mía y con tanto gusto suyo, que buenamente no acertaré a encarecerlo (I, XXVIII: 352).
\end{abstract}

\title{
EL QUIJOTE Y LA IMPRENTA
}

Las disquisiciones sobre lo escrito en Cervantes no son ajenas al papel desempeñado entonces por la tipografía (Chartier 2002b y 2006: 61-87, e Infantes $2005 a$ ), que seguramente no hubiera sido el mismo «sin las nuevas relaciones sociales capitalistas y sin el nuevo inconsciente ideológico que las envolvía» (Rodríguez 2003: 53). Observar que su avance no anuló la actividad manual es algo que ha quedado sobradamente demostrado en las investigaciones realiza- 
das en los últimos años, entre otros factores porque determinadas prácticas de escritura no se confiaron del todo a la imprenta debido a la vigilancia ejercida sobre ésta. Avisos, gacetas, memoriales, instrucciones y libros de autor fueron algunos de los territorios donde el manuscrito mantuvo su presencia y su prestigio, lo mismo que géneros como la poesía, la sátira y el teatro gozaron de una notable circulación por esa vía. Y, por supuesto, sin olvidar la gavilla de pasquines, libelos y carteles infamantes tan del gusto áureo, y aún menos las escrituras personales y cotidianas, siempre dominadas por las cartas y los antes citados libros de memoria y razón.

Contando con eso y con que la llegada de la imprenta tampoco «liberó el conocimiento y lo hizo accesible a todos» (Bernárdez 2005b: 42), es asimismo indiscutible que su avance transformó notablemente la realidad de lo escrito en la Edad Moderna e introdujo aspectos nuevos en lo que concierne al movedizo universo del libro. De un lado, puede decirse que alentó la percepción de que podía vivirse de la literatura, que esta tenía una parte sustancial de mercancía y que el libro debía concebirse como un producto comercial (Rodríguez 2003). De ahí la evolución que experimenta a partir de los años 30 del siglo XVI dentro de lo que se ha llamado «libro moderno» o «libro editorial», entendido ya como un objeto cultural acabado conforme a unas reglas (Petrucci 1988 y Martín 1999: 282-306). El frontispicio se constituye en la carta de presentación que busca al lector a la vez que crecen en importancia los paratextos y entre ellos el prólogo, concebido para proclamar las excelencias de la obra, a veces llegando casi al ridículo, según Cervantes deja ver en el suyo a la primera parte del Quijote ${ }^{8}$. Estos adquieren una relevancia particular por cuanto en ellos los autores marcan sus apuestas, justifican la pertinencia de la obra, sellan su pacto con el lector y pergeñan las propuestas de lectura.

Por otro lado, las ventajas de la cultura impresa en relación a la divulgación de ideas e historias despertaron sintomáticos recelos entre los mismos escritores. En su descargo jugaba el temor a la posible alteración del texto una vez confiado a las distintas manos de los trabajadores del taller tipográfico, por lo que también en esta época se prodigaron apasionados elogios al manuscrito; pero, además, estaba el miedo a la merma de una posición privilegiada asociada al conocimiento socialmente restringido. En esta prospectiva no faltaron, como es notorio, las voces contrarias a los beneficios de la imprenta, siendo buena prueba de ello el conocido diálogo entre Barrildo y Leonelo en Fuente Ovejuna de Lope. Fuera de la literatura, esa mentalidad elitista y proteccionista tuvo su corolario en las prohibiciones y persecuciones desatadas contra las coplas — cantadas, manuscritas o impresas - y los pliegos de cordel, en fin, contra esa literatura de baratillo vendida por buhoneros (Cátedra 2002b: 171-197 y 2004).

8. Este prólogo ha merecido muchas idas y venidas interpretativas, desde la ya clásica de Castro (1941) a las posteriores de Porqueras Mayo (1981), Martín (1993), Díaz Migoyo (2001) y Egido (2004). Sobre la diversa función de los paratextos en el libro español de los Siglos de Oro, Cayuela (1996) y Arredondo, Civil y Moner (2009). 
A pesar de esas voces, es indiscutible que la difusión impresa fue una condición de posibilidad sin la cual sería difícil imaginar la larga circulación cosechada por algunos textos. Aunque el suceso crítico del Quijote no llegara hasta el siglo XVIII, la historia editorial de la primera parte es una prueba fehaciente de lo anterior por la celeridad con la que se sucedieron las más tempranas ediciones, cuatro de ellas en 1605 y a corta distancia de la príncipe ${ }^{9}$. Si ésta se hallaba a la venta en la Navidad de 1604 en Valladolid y semanas más tarde en Madrid, en febrero y marzo se publicaron dos ediciones en Lisboa (Jorge Rodríguez y de Pedro Crasbeeck, ésta en octavo) y poco después otra madrileña por Juan de la Cuesta y la valenciana de Pedro Patricio Mey. Entre este año y la salida al mercado de la segunda parte aparecieron otras cuatro ediciones más: Madrid (Juan de la Cuesta, 1608), Bruselas (Roger Velpius, 1607), Milán (Heredero de Pedromartir Locarni y Juan Bautista Bidello, 1610) y otra vez en Bruselas (Roger Velpius y Huberto Antonio, 1611). Dejando constancia de la confusión entre Bruselas y Amberes, dicha circunstancia fue advertida y celebrada por el mismo Cervantes casi al comienzo de la segunda parte:

—Es tan verdad, señor — dijo Sansón—, que tengo para mí que el día de hoy están impresos más de doce mil libros de la tal historia: si no, dígalo Portugal, Barcelona y Valencia, donde se han impreso, y aun hay fama que se está imprimiendo en Amberes; y a mí se me trasluce que no ha de haber nación ni lengua donde no se traduzca.

—Una de las cosas — dijo a esta sazón don Quijote — que más debe de dar contento a un hombre virtuoso y eminente es verse, viviendo, andar con buen nombre por las lenguas de las gentes, impreso y en estampa (II, III: 706).

En fin, si se considera que la capacidad productiva de la tipografía de entonces podía rondar y hasta superar los 1500 ejemplares por edición ${ }^{10}$, según acreditan los manuales al uso empezando por la Institución y origen del arte de la imprenta de Alonso Víctor de Paredes (ca. 1680) ${ }^{11}$, estaríamos hablando de unos trece mil quinientos quijotes puestos a la venta para atender la demanda del mercado europeo e igualmente americano. En relación con éste, los cálculos más recientes, a partir de los registros de navíos de 1605, han dado como resultado la llegada a América de 525 ejemplares, una cifra que podía suponer la mitad o un tercio de la primera edición (Rueda Ramírez

9. En todo lo que concierne a los avatares del texto del Quijote desde la pluma del autor hasta las diversas impresiones puestas a disposición de lectores y lectoras, con una concluyente mirada a los aspectos ecdóticos del manuscrito al impreso, son imprescindibles las aportaciones de Francisco Rico, ampliamente argumentadas y sistematizadas en sus últimas obras sobre el tema (Rico $2005 a$ y $b$ ).

10. En el caso del Quijote la primera edición pudo alcanzar los 1500-1750 ejemplares, mientras que la segunda de 1605 fue de 1800. Véase Rico (2005a: CCXXIV-CCXXVI).

11. Paredes (2002: 43v-44). Según Francisco Rico (Cervantes 2005: 1250), los «dos mil cuerpos» que se mencionan de Le bagatele en la visita de don Quijote a la imprenta barcelonesa parecen a todas luces excesivos a las posibilidades de la tipografía entonces. 
2005: 233) $)^{12}$. Por otro lado, corrobora el notable suceso de la novela su pronta traducción al inglés por Thomas Shelton (1612), al francés por César Oudin (1614) y al italiano por Lorenzo Franciosini (1622) (Alvar: 2006: 38-40). No se olvide tampoco, como ya vimos, que algunos personajes de la obra se hicieron visibles en no pocas fiestas y mascaradas; que desde muy pronto el Quijote fue aludido o parodiado en la literatura coetánea (Calderón, Lope o Quevedo); que Andreas Bretschneider fue autor del grabado Don Quixote de la Mancha, Cavallero de la Triste Figura (Leipzig, Henning Cross, 1614), en el que aparece la primera imagen conocida del hidalgo junto a las del enano, el cura, el barbero, Dulcinea, Sancho Panza y Maritornes ${ }^{13}$; que Felipe III llamó la atención a un estudiante por el tono alocado de sus risas diciendo de él que «está fuera de sí... o lee la historia de don Quijote» (Rico 1990: 141); y que don Quijote y su escudero llegaron a suplantar a Felipe IV y al valido Olivares en un pasquín difundido en 1641 por los partidarios de la independencia de Portugal ${ }^{14}$.

Las referidas asociaciones entre el Quijote y la imprenta, incorporadas en la trama misma de la novela, llevaron a Marshall McLuhan (1993: 307-310) a considerar el personaje cervantino como un testimonio del homo typographicus y del lector moderno. A partir de aquí se ha insistido mucho en la caracterización de Alonso Quijano como la representación del hombre del libro acarreado por la Modernidad (Vegas González 2006: 151-185). Indudablemente que su figura tiene mucho de ello, sobre todo si la contrastamos con Sancho y otros exponentes de la gente común, pero tampoco don Quijote es ajeno del todo a la oralidad, por más que la suya sea a menudo culta y pegada a las letras.

\section{UNA TEORÍA DE LA LECTURA}

Un elemento más a valorar para medir la importancia de lo escrito en el desarrollo de la trama quijotesca es la atención dispensada por Cervantes a los modos de leer en la época. Así, por ejemplo, vemos cómo el Caballero del

12. Otras estimaciones previas y, en general, para lo que concierne a la difusión de la obra en Indias, Rodríguez Marín (1911), Leonard (1979), González Sánchez (1989 y 1999: 105-106) y Montero Reguera (1992).

13. El grabado se conserva en la Bibliothèque de l'Institut National d'Histoire de l'Art (París), Colecctions Jacques Doucet. A propósito del tan traído cuarto centenario, el Centro de Estudios Cervantinos y Armero Exposiciones y Ediciones publicaron una edición limitada de 500 ejemplares en la navidad de 2005. En lo que atañe a la figura de don Quijote y la similitud del grabado con la descripción literaria de la relación festiva de Pausa, Lucía Megías y Vargas (2005: 212-213). En general, sobre la iconografía cervantina y sus efectos en la lectura de la obra, Lucía Megías (2006b) y Martínez Mata (2009).

14. Conservado en la Hispanic Society of América de Nueva York, Ms. HC 380/80, lo reprodujo Elliott (1990: 601) y, más recientemente, Castilla Gómez (2010: 108). Rodríguez Marín (1942), Estruch Tobella (1992) y Montero Reguera (2006b) se han ocupado de él y de otros aspectos referentes a la apropiación política del Quijote en la coyuntura de 1640-1650. 
Verde Gabán se recrea en aquellas obras que le permiten paladear la lengua, admirar y embelesarse con la invención, es decir, distraerse de otras tareas más exigentes:

Tengo hasta media docena de libros, cuáles de romance y cuáles de latín, de historia algunos y de devoción otros; los de caballerías aún no han entrado por los umbrales de mis puertas. Hojeo más los que son profanos que los devotos, como sean de honesto entretenimiento, que deleiten con el lenguaje y admiren y suspendan la invención, puesto que déstos hay muy poco en España (II, XVI: 823).

Otro tanto podría decirse de Alonso Quijano de no ser porque en él la suspensión no fue únicamente del trabajo y las ocupaciones diarias, sino también del juicio. Conocido es su enloquecimiento por la lectura hasta que al final recupera la cordura; pero antes de eso, su locura le había llevado a confundir la ficción con la realidad o, mejor dicho, a integrarlas en el mismo discurso, que es precisamente el que recorre todas las aventuras quijotescas. Según avisó Melchor Cano, ese riesgo estaba en las entrañas del texto y de él pueden apreciarse numerosas evidencias en el Quijote, unas veces en la cabeza y en el comportamiento del hidalgo y otras en algunos de los secundarios, caso de la trifulca sobre el particular entre el ventero y el cura:

- A otro perro con ese hueso — respondió el ventero- ¡ ¡Como si yo no supiese cuántas son cinco, y adónde me aprieta el zapato! No piense vuestra merced darme papilla, porque por Dios que no soy nada blanco. ¡Bueno es que quiera darme vuestra merced a entender que todo aquello que estos buenos libros dicen sea disparates y mentiras, estando impreso con licencia de lo señores del Consejo Real, como si ellos fueran gente que había de dejar imprimir tanta mentira junta, y tantas batallas, y tantos encantamentos, que quitan el juicio! (I, XXXII: 408-409).

En un elogio inmaculado de la lectura podíamos decir que el comportamiento de Alonso Quijano lleva la misma a su cenit, considerando que éste viene dado por el momento en que lo leído se apodera del lector convirtiéndole en artífice de la historia que se está escribiendo. De ahí su incapacidad para disociar la fantasía de la realidad, interesadamente sacada a colación por la sobrina a la hora de justificar la quema de los libros:

Sepa, señor maese Nicolás (que este era el nombre del barbero), que muchas veces le aconteció a mi señor estarse leyendo en estos desalmados libros de aventuras dos días con sus noches, al cabo de los cuales arrojaba el libro de las manos, y ponía mano a la espada, y andaba a cuchilladas con las paredes; y cuando estaba muy cansado decía que había muerto a cuatro gigantes como cuatro torres, y el sudor que sudaba del cansancio decía que era sangre de las feridas que había recibido en la batalla, y bebíase luego un gran jarro de agua fría, y quedaba sano y sosegado, diciendo que aquella agua era una preciosísima bebida que la había traído el sabio Esquife, un 
grande encantador y amigo suyo. Mas yo me tengo la culpa de todo, que no avisé a vuestras mercedes de los disparates de mi señor tío, para que los remediaran antes de llegar a lo que ha llegado, y quemaran todos estos descomulgados libros, que tiene muchos que bien merecen ser abrasados, como si fuesen de herejes (I, V: 80-81).

La excusa de la locura habría servido al autor para exaltar la lectura de entretenimiento frente a las diatribas levantadas contra la misma en la España de la Contrarreforma. El hidalgo habría encontrado en ella el revulsivo para comprender la ruindad de su mundo y su vida dando paso a otras posibilidades, las que se le abren con cada aventura (Rodríguez 2003: 91-92). Apoyándose en la genuina confusión entre la literatura y la vida representada por don Quijote, en la mejor tradición del libro encarnado, una primera interpretación llevaría a pensar, como ha señalado Javier Blasco (2005: 25), que «la finalidad del texto no es la de ser leído, sino la de transformarse en materia de la que se alimenta la vida». Sin embargo, como recuerda este autor, evocando la afirmación de Foucault (1999: 55) conforme a la cual «la escritura y las cosas no se asemejan», es evidente que «los libros se leen, pero no se viven» por cuanto «lo leído y lo vivido corresponden a niveles de realidad no equiparables» (Blasco 2005: 25-26). Esto haría de don Quijote un lector en formación en la medida que se muestra incapaz de entender que la historia empieza y concluye en el propio texto. En palabras de Martín Morán, «Alonso Quijano es un lector novel, con una cultura oral, como buen hidalgo de aldea, que aún no ha asimilado la predisposición mental que la lectura solitaria exige, y sigue comportándose como un oidor de una sesión de lectura pública, en la que el narrador exige la participación del público en la acción» (Martín Morán 1997a: 126-127).

Contemporáneamente a Alonso Quijano, Cervantes creó otro personaje que enloqueció leyendo libros: Bartolo, el labrador de El entremés de los romances, escrito probablemente después del Quijote (Murillo 1986), quien movido por la locura se marchó a la guerra:

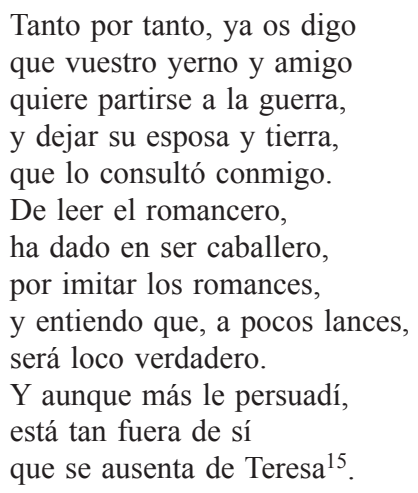


En ambos la determinación de romper con la vida y con las convenciones inherentes a ella arranca de la lectura. Ésta hace que el hidalgo Alonso Quijano y el campesino Bartolo abandonen todo: uno en busca de aventuras con las que emular las de los caballeros andantes y el otro para serlo también pero guerrero. Locura o no, el dilema tiene su interés pues encubre, o puede hacerlo, una argucia cervantina para manifestar una palabra más libre. Tampoco falta quien ha visto en ello un ejercicio terapéutico que habría servido para sacar al protagonista de la crisis y de la represión derivadas de unos hábitos sociales que no casaban con su pensamiento (Imperiale 2001: 497). Cervantes, por lo tanto, nos introduce en una problemática de enorme calibre cualquiera que sea el lado desde donde la miremos. Por una parte, es inevitable pensar en tal artimaña como una forma velada de criticar la situación social y política, en suma, la crisis que horadaba los cimientos de la Monarquía hispánica. Por otra, en un terreno circunscrito a la materia que estamos tratando aquí, el autor nos mete de lleno en el debate sobre los buenos y malos libros y el orden de las lecturas (Castillo Gómez 2003a). En este punto la perspectiva cervantina entronca con la general condena de los libros de entretenimiento y en especial de las obras de caballerías que puede rastrearse en los preceptistas y, más acusadamente, en los moralistas de los siglos XVI y XVII (Sarmatti 1996; Riquer 2003: 99-113; Blasco 2005: 22-42 y 85-94). Para Vives, por ejemplo, las lecturas de ese aire sólo tenían fundamento si colaboraban a la comprensión de lo primordial, si aderezaban el camino para alcanzar la verdad que los libros debían procurar. Otros, como Juan de la Cerda, cronológicamente más próximo a Cervantes, se mostraron bastante más firmes descalificando dichos libros como «dulces venenos» ${ }^{16}$. Tamaño recelo hacia la lectura de dichos libros tuvo su eco en la conocida disposición adoptada en las Cortes de Valladolid en 1555:

Otrosí, decimos que está muy notorio el daño que en estos reinos ha hecho y hace a hombres mozos y doncellas e a otros géneros de gente leer libros de mentiras y vanidades, como son Amadís y todos los libros que después dél se han fingido de su calidad y lectura, y coplas y farsas de amores y otras vanidades; como porque los mancebos y doncellas por su ociosidad principalmente se ocupan en aquello, desvanécense y aficiónanse en cierta manera a los casos que leen en aquellos libros haber acontecido, ansí de amores como de armas y otras vanidades, y aficionados, cuando se ofrece algún caso semejante, danse a él más a rienda suelta que si no lo oviesen leído... Y para remedio de lo susodicho, suplicamos a V. M. mande que ningún libro déstos se lea ni imprima so penas graves; y los que agora hay los mande recoger y quemar... (Riquer 2003: 106-106).

16. «hay algunas doncellas que, por entretener el tiempo, leen en estos libros, y hallan en ellos un dulce veneno que les incita a malos pensamientos y les hace perder el seso que tenían». Juan de la Cerda, Vida política de todos los estados de mujeres, Alcalá de Henares, Juan Gracián, 1599, fol. 41v. Véase al respecto Seres (2004: 69). 
¿Se suma Cervantes a tan condena o la subvierte? Más bien cabe pensar en la segunda opción y entender así que uno de los ejes del Quijote tiene algo que ver con una cierta exaltación de la lectura, incluida su función transgresora. Si esto se puede deducir de la práctica sostenida por algunos varones, todavía parece más claro en el caso de las mujeres (Bernárdez 2005a-b). Varias son las que como Dorotea y Luscinda dicen leer o haber leído libros de caballerías. La primera lo hace cuando asume el papel de la princesa Micomicona aduciendo que «ella había leído muchos libros de caballerías y sabía bien el estilo que tenían las doncellas cuitadas cuando pedían sus dones a los caballeros andantes» (II, XXIX: 367). De Luscinda lo refiere el joven Cardenio al comentar las aficiones y virtudes de su enamorada: «Acaeció, pues, que habiéndome pedido Luscinda un libro de caballerías en que leer, de quien era ella muy aficionada, que era el de Amadís de Gaula...» (I, XXIV: 292).

En este orden, el manifiesto lector de Cervantes comporta también una clara apelación a la lectura entendida como goce. Es la suya una propuesta nueva tanto en la escritura como en el modo de leer (Egido 2004: 42). Frente a la lectura mediatizada de los textos glosados y comentados tan del gusto erudito, el autor pone en manos del lector un texto libre de esos abundosos preliminares tan comunes a los libros de la época, en los que no faltaban sonetos, epigramas y encendidos elogios al autor, al igual que las citas y anotaciones marginales y finales usadas como argumento de autoridad. Todo ello impedía la función principal que debía perseguir un texto literario, esto es, seducir y conmover a los lectores, como el autor anticipa en el prólogo de la primera parte:

\footnotetext{
Y pues esta vuestra escritura no mira a más que a deshacer la autoridad y cabida que en el mundo y en el vulgo tienen los libros de caballerías, no hay para qué andéis mendigando sentencias de filósofos, consejos de la Divina Escritura, fábulas de poetas, oraciones de retóricos, milagros de santos, sino procurar que a la llana, con palabras significantes, honestas y bien colocadas, salga vuestra oración y período sonoro y festivo, pintado en todo lo que alcanzáredes y fuere posible vuestra intención, dando a entender vuestros conceptos sin intrincarlos y escurecerlos (I, «Prólogo»: 19).
}

La invitación a la lectura que inaugura la obra es, de hecho, la que Cervantes pone en pie con Alonso Quijano, sobre todo a partir del capítulo VI donde se narra el «donoso escrutinio» de su librería. Aparte de algún caso de la literatura oriental, en especial Las mil y una noches, dicho pasaje representa una de las primeras utilizaciones literarias de la biblioteca como eje de la narración (López Estrada 1994); y no sólo de ésta, sino también del libro como instrumento de comunicación. Puede decirse, pues, como lo ha hecho Martín Morán, que «por primera vez, un libro reflexiona sobre su propia tecnología de difusión, sobre la imprenta y sus efectos en el mundo, sobre el libro como objeto de cultura que ha cambiado la percepción de la realidad» (Martín Morán 1997b: 339-340).

En el referido capítulo se mencionan algunas de sus lecturas preferidas, encabezadas por los relatos de caballerías, las novelas pastoriles, poemas 
épicos, cancioneros y libros de historia, así hasta constituir un fondo de unos trescientos volúmenes que integraban su biblioteca (I, 24) ${ }^{17}$. Sin duda, más que nutrida para un hidalgo rural $\mathrm{y}$, por supuesto, mayor que cualquiera otra de las homónimas que se mencionan en la obra, por ejemplo la de Diego de Miranda, que no alcanzaba los ochenta ejemplares:

Tengo hasta seis docenas de libros, cuáles de romance y cuáles de latín, de historia algunos y de devoción otros; los de caballerías aún no han entrado por los umbrales de mis puertas. Hojeo más los que son profanos que los devotos, como sean de honesto entretenimiento, que deleiten con el lenguaje y admiren y suspendan con la invención, puesto que déstos hay muy pocos en España (II, XVI: 823).

Al tiempo que se suceden las reflexiones sobre el libro, la autoría y el proceso de creación literaria, lo hacen también la recepción y los modos de leer la propia obra que se está escribiendo y por extensión la literatura coetánea. En tal sentido se ha dicho, y con razón, que «si hay un libro en el que la lectura o, de manera más concreta la reflexión crítica sobre aquélla esté presente desde el primer momento, ése es El Quijote» (Montero Reguera 2005: 11). Para Cervantes, el verbo leer designa primordialmente la práctica sostenida en silencio, lo que McLuhan y otros críticos equiparon a la modernidad lectora. Sin embargo, para Covarrubias dicho término se relacionaba más con la lectura en voz alta de acuerdo a la definición que incluye en su Tesoro de la lengua castellana o española (1611): leer «es pronunciar con palabras lo que por letras está escrito» ${ }^{18}$. Sólo cuando la lectura no es silenciosa Cervantes recurre a expresiones que la aclaren, como acontece cada vez que algún analfabeto, Teresa, por ejemplo, deben leer una carta (II, 50: 1133) ${ }^{19}$; o cuando en el palacio de los Duques se lee públicamente la misiva de don Quijote a Sancho por no contener nada digno de secreto: «Bien se puede leer en voz alta, que lo que el señor don Quijote escribe a vuestra merced merece estar estampado y escrito con letras de oro» (II, LI: 1144). Así mismo la diferencia se establece en aquellas circunstancias en que pudieron darse ambas modalidades, singularmente en el pasaje referido a la lectura de la Novela del Curioso impertinente, leída por el cura y Cardenio «para sí», y luego en público para quienes estaban en la venta con voluntad, como Dorotea, de «entretener el tiempo oyendo algún cuento»:

Llevábase la maleta y los libros el ventero, mas el cura le dijo:

-Esperad, que quiero ver qué papeles son esos que de tan buena letra están escritos.

17. La diversidad de sus lecturas queda reflejada en distintos pasajes de la obra por las reflexiones que expone sobre la historia (I, IX y II, XIII), la comedia (I, XII y II, XVI) o la poesía (II, XVI).

18. Sobre los sentidos y modos de la lectura en el Siglo de Oro, véase Frenk (1997, 2003 y 2004) y Chartier (2003 y 2005b).

19. En torno a las relaciones con lo escrito de las personas analfabetas en el Quijote, puede verse Sierra Macarrón (2001 y 2004). 
Sacolos el huésped, y, dándoselos a leer, vio hasta obra de ocho pliegos escritos de mano, y al principio tenían un título grande que decía: Novela del Curioso impertinente. Leyó el cura para sí tres o cuatro renglones y dijo:

- Cierto que no me parece mal el título desta novela, y que me viene voluntad de leella toda.

A lo que respondió el ventero:

-Pues bien puede leella su reverencia, porque le hago saber que algunos huéspedes que aquí la han leído les ha contentado mucho, y me la han pedido con muchas veras; mas yo no se la he querido dar, pensando volvérsela a quien aquí dejó esta maleta olvidada con estos libros y esos papeles, que bien puede ser que vuelva su dueño por aquí algún tiempo, y aunque sé que me han de hacer falta los libros, a fe que se los he de volver, que, aunque ventero, todavía soy cristiano.

- Vos tenéis mucha razón, amigo — dijo el cura-, mas, con todo eso, si la novela me contenta, me la habéis de dejar trasladar.

-De muy buena gana - respondió el ventero.

Mientras los dos esto decían había tomado Cardenio la novela y comenzado a leer en ella; y pareciéndole lo mismo que al cura, le rogó que la leyese de modo que todos la oyesen (I, XXXII: 410).

En la medida que el delirio de don Quijote tuvo origen en «ese acto solitario, desposeído de toda comunión con los demás, alejado de la identidad colectiva que la lectura pública refuerza» (Martín Morán 1997: 341), el contraste señalado entre el leer en silencio, eminentemente privado, y en alta voz, casi siempre en público y grupal, enlaza con algunas de las reflexiones esgrimidas por Walter Ong (1993) respecto a las diferencias entre la oralidad y la escritura. Fue este autor quien apuntó que la primera une a los individuos al hacerles compartir contemporáneamente un acto de comunicación, mientras que la segunda los distancia - físicamente diría yo — al distinguir los momentos en que podía ocurrir la escritura de un texto y su apropiación. Algo de ello puede, sin duda, rastrearse en la dualidad que Cervantes plantea entre ese don Quijote ensimismado y encerrado en su imaginación, y Sancho, o el ventero que no se cansaba de oír leer noche y día (I, XXXII: 405), más habituados a compartir experiencias, a disfrutar y reír en compañía, y eventualmente a gozar de la lectura efectuada por uno para los demás.

No voy a reiterar aquí los argumentos que se han vertido en distintas obras sobre la lectura en alta voz, pero sí conviene detenerse en algunos puntos. En primer lugar, debe recordarse que tal modalidad lectora no era exclusiva de los sectores más populares por cuanto también se practicaba en ambientes cortesanos, aunque la función no fuera siempre la misma (Chartier 1992: 121-144). En unos casos, leer en alta voz era una parte más de las actividades del ocio aristocrático y en cuanto tal una forma de distinción. En otros, sin embargo, dicha manera de leer contribuyó a una mayor divulgación de los textos. En cuanto a esta segunda opción, algunos autores han planteado la inverosimilitud de las escenas de las lecturas campesinas de libros de ca- 
ballería (Chevalier 1999); pero, incluso considerando esta hipótesis, eso no resta valor al sentido de unos testimonios que, sin embargo, nos aproximan a una realidad perfectamente documentada en aquellos días, ya que existe constancia de que dichos libros circularon y fueron leídos en ámbitos rurales no demasiado letrados (Nalle 1989).

Algunas de las gentes letradas que aparecen por la obra se dignan efectuar una lectura que distingue perfectamente entre el libro y la realidad; practican un leer solitario y de estudio cuya extensión se manifestaba en la propia escritura. El modo de hacerlo de don Quijote también lo es silencioso y privado pero no ligado al estudio sino al disfrute de lo leído. Representa por ello una exaltación de una tipología de lector que adquirió mayor relieve con la difusión tipográfica, pero que no se puede confundir con una invención asociada a la imprenta puesto que, amén de algunos testimonios clásicos, su «nacimiento» estuvo vinculado a los cambios acarreados por la Universidad medieval de los siglos XII a XIV y a su posterior difusión social en los tiempos finales de la Edad Media (Petrucci 1999: 188-195). Obviamente, en la medida que la tipografía abarató los costes de producción del escrito e hizo factible una circulación sensiblemente mayor, sí debe atribuírsele una contribución significativa a la popularización de ese modelo de lectura tan expresivamente representado en don Quijote.

Así pues, la teoría de la lectura que desarrolla Cervantes presenta diversas e interesantes perspectivas que traen al texto una buena muestra de la realidad lectora de la época. Un elogio del leer que encuentra reflejo en muchas afirmaciones del hidalgo, entre otras ésta con la que quiero ir concluyendo:

\begin{abstract}
Y vuestra merced créame y, como otra vez le he dicho, lea estos libros, y verá cómo le destierran la melancolía que tuviere y le mejoran la condición, si acaso la tiene mala. De mí sé decir después que soy caballero andante soy valiente, comedido, liberal, bien criado, generoso, cortés, atrevido, blando, paciente, sufridor de trabajos, de prisiones, de encantos; y aunque ha tan poco que me vi encerrado en una jaula como loco, pienso, por el valor de mi brazo, favoreciéndome el cielo y no me siendo contraria la fortuna, en pocos días verme rey de algún reino, adonde pueda mostrar el agradecimiento y liberalidad que mi pecho encima (I, L: 625-626).
\end{abstract}

Si la historia de la primera parte corresponde a la de un ingenio afectado por la lectura, la de la segunda lo es de quienes han leído la anterior, mostrando así la riqueza del arte de novelar puesto en danza por Cervantes, muy apreciado por Thomas Mann en su Viaje por mar con Don Quijote (1945):

En Cervantes hay en juego mucha más confusión romántica y magia irónica. Don Quijote y su escudero salen en esta segunda parte de la esfera de la realidad a la que pertenecen, es decir, del libro de la novela en el que vivían, y se mueven, saludados ruidosamente por los lectores de su historia, en carne y hueso como realidades potenciadas en un mundo que, al igual que ellos, en relación con el anterior, el mundo impreso, representan un 
nivel superior de la realidad, aunque también ella es mundo narrado, la invocación ilusoria de un pasado ficticio, como cuando Sancho se permite la broma de decir a la duquesa: «... y aquel escudero suyo que anda, o debe de andar, en la tal historia, a quien llaman Sancho Panza, soy yo, si no es que me trocaron en la cuna; quiero decir, que me trocaron en la estampa» (Mann 2005: 42-43).

El Quijote se mueve entre la cultura de transmisión oral y el nuevo mundo de la transmisión impresa (Bernat 2001b: 675). Representa un excelente laboratorio de los contactos establecidos entre la literatura y el mundo social, de las negociaciones permanentes entre la creación poética y el mundo más prosaico de la imprenta, la tinta y sus tipos (Chartier 2002b y 2006: 61-87), de la cultura escrita en general. En suma, los textos cervantinos, con el Quijote a la cabeza, bien pueden leerse y analizarse como un espejo donde se refleja y expone un sustancioso puñado de los desafíos, prácticas y tensiones de lo escrito en el Siglo de Oro, siendo por ello, como hemos visto, más que llamativa la recurrencia con la que ciertos temas y motivos de esa índole se prodigan en las obras de Cervantes, como también de sus contemporáneos.

\section{NOTA BIBLIOGRÁFICA}

La bibliografía cervantina crece de tal modo que cualquier estado de la cuestión no sólo está amenazado de envejecimiento prematuro sino, lo que aún es peor, de incompleto y desequilibrado. Si encima le sumamos los abundosos e irregulares frutos de la cosecha conmemorativa del cuarto centenario de la edición príncipe del Quijote, la tarea se convierte en una empresa casi de gigantes. Encauzar esos copiosos ríos de tinta no es asunto de mi competencia, pues Cervantes y sus textos tienen especialistas suficientes para dicho menester. Mi labor, por el contrario, se reduce a bosquejar unas últimas líneas bibliográficas referidas a los temas que he tratado en las páginas precedentes. Como tampoco quiero caer en la tan fatigosa como aburrida enumeración de autores y obras me contentaré con señalar los principales derroteros que se han seguido y los espacios del escrito exhumados ${ }^{20}$.

Rescatada de esas «tinieblas de la pluma» donde la situaba Saavedra Fajardo en su República Literaria (1612), la actividad manuscrita puede que sea una de las modalidades de escritura que más se ha beneficiado del suceso alcanzado por este ámbito de estudios en los últimos lustros (Chartier 2000: 137-156; Bouza 2001). Pero más allá de cuanto afecta a la importante circulación y transmisión por esa vía de piezas literarias o a las relaciones entre manuscritos

20. A falta de un verdadero estado de la cuestión sobre la escritura, el libro y la lectura en la Edad Moderna, imposible de acometer en estas páginas, se puede acudir complementariamente a las valoraciones de Barreiro Mallón (2003), Rey Castelao (2003: 19-27 y 77-91), López (2005) y Montero-Ruiz Pérez (2006). 
e impresos en el taller tipográfico, objeto más atendido por el gremio de filólogos (Rico 2000; Garza 2005 y 2009, y García Aguilar 2009), por la orientación dada a este ensayo quiero desviar la mirada hacia otro sendero, el que se interna por el tupido bosque del escribir cotidiano. Su consecuencia más clara es, por un lado, un mejor conocimiento de la amplitud alcanzada por la escritura en el ámbito privado (cartas, libros de cuentas, libros de memorias, autobiografías, etc. $)^{21}$, matizando de paso las conclusiones señaladamente cuantitativas a que llegaron algunos de los primeros estudios sobre el alfabetismo en la Edad Moderna (De l'alphabétisation 1987). Y por otro, una valorización de las escrituras expuestas (Castillo Gómez 2009a y 2010), que casi habían pasado desapercibidas, tanto en sus materializaciones más epigráficas o monumentales (Castillo Gómez 2000a y 2009a; Gimeno Blay 2005) como en las versiones efímeras representadas por pasquines, carteles infamantes o graffiti (Castillo Gómez 1999, 2006 y 2009c; Bouza 2000 y 2008: 95-109 y 131-178; Gascón 2003; Navarro Bonilla 2006 y Ruiz Astiz 2009a-b y 2010). En la medida que todas o muchas de estas prácticas tuvieron su debida resonancia en la literatura áurea, tampoco faltan quienes se han ocupado de seguir la pista a esos ecos, unas veces considerando exclusivamente el texto literario y otras cruzándolo con la información que suministran otras fuentes de carácter más documental (Egido 2003; Navarro Bonilla 2002 y 2004). En esa prospectiva, como se ha podido ver, la obra de Cervantes ha sido particularmente atendida por cuanto constituye un filón casi inagotable de los significados y apropiaciones del escrito en la sociedad del Siglo de Oro.

Del igual modo que, durante un cierto tiempo, el brillo de la imprenta eclipsó los fértiles territorios del manuscrito, la singular escritofilia de nuestra cultura hizo lo propio con otras formas de creación y comunicación, en parte con la imagen y sobre todo con la oralidad. Respecto a esta, aunque todavía nos faltan obras tan ambiciosas como la de François Waquet (2003) sobre la llamada «oralidad culta», al menos en los últimos años se han empezado a dar algunos progresos en ese camino. Y no me refiero al ámbito de la «literatura oral», más cultivado por determinados filólogos (Pedrosa 1999 y 2004), sino a la necesidad de recuperar las diversas manifestaciones de la palabra hablada en el contexto cultural de los siglos XVI y XVII, en calles y palacios, universidades e iglesias, teatros y tabernas (Bouza 2003: 21-34; Castillo Gómez

21. Un buena porción de estas expresiones de la scribal culture hispana han merecido el fino análisis de Fernando Bouza en distintos ensayos escritos entre 1996 y 2000, después revisados y recogidos en su libro Corre manuscrito (2001), al que se suma el más reciente (2010: 35-67). Por mi parte, le dediqué algunos capítulos de mi tesis doctoral, leída en 1995 (1997), volví a recalar en ello a raíz de un particular «viaje al país de las denuncias» (1999b) y he seguido dándole vueltas en distintas ocasiones (1998 y 2001a) hasta rematar, por ahora, en bastante de lo que compone Entre la pluma y la pared (2006) y alguna otra aproximación más puntual (2008). En lo que concierne a los libros de familia y libros de memorias debe acudirse a la síntesis de Xavier Torres Sans (2000); mientras que para los escritos autobiográficos de la gente común es imprescindible la amplia producción de James Amelang, con parada obligada en su libro El vuelo de Ícaro (2003). A su vez, para la fecunda producción de la autobiografía espiritual me remito a Poutrin (1995), Herpoel (1999) y Amelang (1990 y 2005). 
2005a; y García Martínez 2006). Un terreno que devuelve al primer plano las prácticas de la lectura en alta voz, sobre las que aún nos falta conocer algunos elementos de la performance; al igual que la materialidad del escrito, una vez que se ha advertido el efecto de sentido que pueden entrañar aspectos tales como la disposición de la escritura, las tipologías gráficas, la arquitectura textual, la distribución de la página o las interacciones entre lo icónico y lo verbal (Infantes 2006 y Torné 2006). En lo que atañe al Quijote y a otros textos cervantinos, la dialéctica oral-escrito se ha rastreado al abrigo de las tensiones culturales de la época y, sobre todo, al analizar las maneras literarias de Cervantes. A eso puede añadirse la permanente evocación de pasajes cervantinos en muchos de los ensayos referentes a las formas de la lectura en el Siglo de Oro (Frenk 1997, 2003 y 2004; Chartier 2003 y 2005b), pues en ellos encontramos testimoniado desde el lector enloquecido hasta el oyente embelesado, desde la lectura privada en el estudio a la pública y comunitaria en la calle u otros espacios.

No menos conocido es el recurso al Quijote para ilustrar el funcionamiento de los talleres tipográficos (Grupo Prinqeps 1605 2009), tan impagablemente descrito en la visita a la imprenta barcelonesa en la segunda parte de la obra (Burgos Rincón 2005) 22 . Sumado a otros muchos, dicho episodio pone de relieve la importancia que el mundo de los libros tiene en el imaginario cervantino y, en particular, en ese «libro de libros» que es el Quijote (Moner 1989: 90). Hace años, Marcelino Menéndez Pelayo (1941) y Américo Castro (1947) aludieron a ello en sendos ensayos sobre la cultura literaria del autor y las implicaciones de lo escrito en la obra. En fechas más cercanas, la crítica cervantina ha retomado algunos de esos lugares al objeto de desvelar las estrategias de simulación desplegadas por el autor y los rasgos del proceso creativo de la novela (Asensi 1996; Martín Morán 1998; Rodríguez 2003; Blasco 2005; y Martínez Mata 2008). Significativos son también los estudios que han tratado de dar cuerpo a la biblioteca del hidalgo y por extensión a la de Cervantes (Eisenberg 1991; Baker 1997; Infantes 2005b), los que han tenido su punto de mira en los libros de caballerías y los modos de leerlos (Marín Pina 1993 y 2005; Lucía Megías 2001 y 2003; Aguilar Perdomo 2005; Cátedra 2007) o los que se han ocupado de reflexionar sobre la teoría cervantina de la lectura, ya sea desde una óptica literaria o desde otra más erudita ${ }^{23}$.

No debemos olvidar, en fin, que la historia de la cultura escrita, al igual que cualquier otra, es siempre una historia de personas, de hombres y mujeres,

22. Sobre el trabajo impresor y las características formales del libro impreso, la bibliografía crece al ritmo que lo hacen los estudios sobre imprenta y crítica textual. Remito principalmente a Jaime Moll (1994) y Simón Díaz (2000), a los ensayos reunidos en Francisco Rico (2000), a distintos trabajos de éste (Rico 1998, 1999, 2002a, $2002 b$ y 2004) y a Julián Martín Abad (2004). Centrado en los problemas inquisitoriales de algunos trabajadores del ramo, es fundamental Griffin (2009). Por último, para un selecto conjunto de testimonios literarios y documentales sobre el mundo de la imprenta, Lucía Megías (2005).

23. Amén de distintos artículos, algunos ya citados, remito a los ensayos monográficos de Fuentes (1976), Frenk (1997), Bernárdez (2000) y Blasco (2005). 
alfabetizados y analfabetos. En relación con esto deben considerarse los estudios sobre los contenidos, métodos, instrumentos y espacios de la enseñanza/ aprendizaje de la escritura y de la lectura (Gimeno Blay 1995 y 1997; Infantes 1995 y 1998; Infantes y Martínez Pereira 2000 y 2003; y Martínez Pereira 2006). Obviamente la atención a la identidad y condición de quienes escribieron, leyeron o solicitaron hacerlo durante la Edad Moderna es un asunto que también debe señalarse en esta nota. Es cierto que buena parte de esos trabajos son aún deudores de una tradición empeñada en desempolvar libros y bibliotecas por vía de inventarios, unas veces personales y otras de librerías (Bécares e Iglesias 1992; Griffin 1988 y 1998; Dadson 1998; Cayuela 2005; y Agulló Cobo 2010); pero no lo es menos que en la etapa más reciente se ha desarrollado una línea de investigación interesada en los lectores y en la circulación social de los libros (Wernaga Prieto 1993 y 2008; Peña Díaz 1996, 1997 y 2001; Cátedra 2002a; Luengo Pacheco 2002; Rey Castelao 2003; Prieto Bernabé 2004; y Rial Costas 2007), incluyendo en ella los efectos y transgresiones de la censura inquisitorial (Peña Díaz 2002, 2004 y 2005).

Dentro de esta corriente algunos estudios se han centrado en determinados lectores, mayormente reyes, nobles y gentes de letras, cuya memoria documental y bibliográfica siempre cuenta con más vestigios (Ruiz Pérez 1997; Bouza $1999 b$ y 2005b; Cátedra 2002c; Gonzalo Sánchez-Molero 2004; Agulló Cobo 2010; e Infantes 2010). La dificultad de rastrear la práctica de lectores más humildes se ha suplido en parte con trabajos sobre las modalidades de lectura y la difusión de la literatura popular (García de Enterría 1973; Infantes 2001; Cátedra 2002b y 2006). Destacar asimismo aquellos otros referidos expresamente al acceso y apropiación de la cultura escrita por parte de las mujeres (Luna 1996; Cátedra y Rojo 2004; Baranda Leturio 2005).

El paso del objeto libro a la lectura ha supuesto también un mayor miramiento a las formas de leer, ya se trate de las sostenidas en medios eruditos (Bouza 2002; Peraita Huerta 2003 y 2004; Castillo Gómez 2001-2002), en ámbitos religiosos y conventuales (Álvarez Santaló 1999 y 2003; y González Sánchez 2003), o en entornos más populares (García de Enterría 1999); o las que conciernen al modo de efectuar la lectura, en silencio o en voz alta, en privado o en público, solo o en comunidad (Castillo Gómez $2000 b$ y 2005) ${ }^{24}$.

Comprendo que un repaso tan apresurado como este no puede ser exhaustivo y a buen seguro que se pueden echar autores y obras en falta. Mi objetivo, sin embargo, no era concluir con un amplio estado de la cuestión pues esto hubiera requerido todas las páginas de este trabajo y algunas más. Sólo he querido anotar a lo que me ha parecido esencial, sobre todo en función de los temas que he revisado en este paseo por las huellas de lo escrito en algunos textos de Cervantes con el Quijote a la cabeza.

24. Una visión de conjunto donde están patentes buena parte de esos cambios de objeto y enfoque acontecidos en los últimos lustros nos la ofrece la primera parte de la Historia de la edición y de la lectura en España, dedicada al período 1472-1680 (Infantes, Lopez y Botrel 2003). 


\section{REFERENCIAS}

Aguilar Perdomo, María del Rosario, «La recepción de los libros de caballerías en el siglo XVI: a propósito de los lectores en el Quijote», Literatura: teoría, historia, crítica, 7 (2005), pp. 45-67.

Aguilló Cobo, Mercedes, A vueltas con el autor del «Lazarillo». Con el testamento e inventario de bienes de Don Diego Hurtado de Mendoza, Calambuz, Madrid, 2010.

AlCANTARILla, Ricardo, y LuCía MEgías, José Manuel, «Bibliografía sobre la imprenta en la España del Quijote», en J. M. Lucía Megías, ed., Imprenta, libros y lectura, 2006, pp. 499-527.

Alvar, Carlos, «Las traducciones del "Quijote"», Edad de Oro, XXV (2006), pp. 35-51.

Alvar, Carlos y Lucía Megías, José Manuel, eds., El delirio y la razón. Don Quijote por dentro: Alcalá de Henares, Capilla del Oidor, del 25 de abril al 12 de junio de 2005, Fundación Camino de la Lengua, Logroño, 2005.

ÁlVAREZ SANTALÓ, León Carlos, «Religiosidad moderna y cultura lectora en la España de los siglos XVI al XVIII», en Antonio Luis Cortés Peña y Miguel Luis López-Muñoz, eds., Estudios sobre iglesia y sociedad en Andalucía en la Edad Moderna, Universidad de Granada, Granada, 1999, pp. 225-265.

Álvarez Santaló, León Carlos, "Algunos usos del libro y la escritura en el ámbito conventual: el "Desengaño de religiosos" de sor María de la Antigua (1614-1617)», en Carlos A. González Sánchez y E. Vila Vilar, coords., Grafías del imaginario. Representaciones culturales en España y América (siglos XVI-XVIII), FCE, México, 2003, pp. 157-202.

AmELANG, James. S., «Los usos de la autobiografía: monjas y beatas en la Cataluña moderna», en James S. Amelang y Mary Nash, eds., Historia y Género. Las mujeres en la Europa Moderna y Contemporánea, Edicions Alfons el Magnánim, 1990, pp. 191-212.

AmELANG, James. S., El vuelo de Ícaro. La autobiografia popular en la Europa Moderna, Siglo XXI, Madrid, 2003; ed. orig. The Flight of Icarus. Artisans Autobiography in Early Modern Europe, Stanford University Press, Stanford, California, 1998.

AmElANG, James. S., «Autobiografías espirituales», en Isabel Morant, dir., Historia de las mujeres en España y América Latina, vol. II, El mundo moderno, coord. Margarita Ortega, Asunción Lavein y Pilar Pérez Cantó, Cátedra, Madrid, 2005, pp. 155-168.

Arredondo, María Soledad; Civil, Pierre y Moner, Michel, eds., Paratextos en la literatura española. Siglos XV-XVIII, Casa de Velázquez, Madrid, 2009.

ASENSI, Manuel, La maleta de Cervantes o el olvido del autor, Episteme, Valencia, 1996.

BAKer, Edward, La biblioteca de don Quijote, Marcial Pons, Madrid, 1997.

Baranda Leturio, Nieves, Cortejo a lo prohibido. Lectoras y escritoras en la España Moderna, Arco/Libros, Madrid, 2005.

BARREIRo MALlón, Baudilio, «Revisionismo metodológico y metodología aplicada en la historiografía de la cultura letrada española de las dos últimas décadas», en Domingo L. González Lopo y Roberto J. López López, coords., Balance de la historiografía modernista, 1973-2001. Actas del VI Coloquio de Metodología Histórica Aplicada (Homenaje al profesor Antonio Eiras Roel), Xunta de Galicia, Santiago de Compostela, 2003, pp. 335-367.

BernáRDeZ, Asunción, Don Quijote, el lector por excelencia (Lectores y lectura como estrategias de comunicación), Huerga \& Fierro, Madrid, 2000.

BERNÁRDEZ, Asunción, «Las mujeres lectoras en el Quijote», en Fanny Rubio, ed., El «Quijote» en clave de mujer/es, Editorial Complutense, Madrid, 2005a, pp. 283-304.

BERNÁRDEZ, Asunción, «Lectura, mujeres y poder en El Quijote», Letra internacional, 87 (2005b), pp. 41-47. 
Bernat Vistarini, Antonio, ed., Volver a Cervantes. Actas del IV Congreso internacional de la Asociación de Cervantistas, Universitat de les Illes Balears, Palma de Mallorca, 2001a, $2 \mathrm{v}$.

BERNAT VISTARINI, Antonio, «"Componer libros para dar a la estampa” y las maravillas de la cueva de Montesino», en A. Bernat Vistarini, ed., Volver a Cervantes, 2001b, I, pp. 671-684.

Blasco, Javier, Cervantes, raro inventor, Centro de Estudios Cervantinos, Alcalá de Henares, 2005.

BouZA, Fernando, Comunicación, conocimiento y memoria en la España de los siglos XVI y XVII, Seminario de Estudios Medievales y Renacentistas (SEMYR): Universidad de Salamanca, Salamanca, 1999a.

BouzA, Fernando, «Docto y devoto. La biblioteca del Marqués de Almazán y Conde de Monteagudo (Madrid, 1591)», en Friedrich Edelmayer, Alfred Kohler y José Carlos Rueda Fernández, eds., Die Epoche Philipps II (1556-1598)/La época de Felipe II (1556-1598), Verlag für Geschichte und Politk-R. Oldenbourg Verlag, Viena-Munich, 1999b, pp. 247-310.

BouZA, Fernando, «Servidumbres de la soberana grandeza. Críticar al rey en la corte de Felipe II», en Alfredo Alvar, coord., Imágenes históricas de Felipe II, Centro de Estudios Cervantinos, Alcalá de Henares, 2000, pp. 141-179.

BouZA, Fernando, Corre manuscrito. Una historia cultural del Siglo de Oro, Marcial Pons, Madrid, 2001.

BouZA, Fernando, «"No puedo leer nada”. El Corrector General Juan Vázquez del Mármol y la cultura escrita del Siglo de Oro», Syntagma. Revista del Instituto de Historia del Libro y de la Lectura, 0 (2002), pp. 19-45.

BouzA, Fernando, Palabra e imagen en la Corte. Cultura oral y visual de la nobleza en el Siglo de Oro, Abada, Madrid, 2003.

BouZA, Fernando, «Los contextos materiales de la producción cultural», en A. Feros y J. Gelabert, dirs., España en tiempos del Quijote, 2004, pp. 309-344.

BouzA, Fernando, coord., Cultura epistolar en la alta Edad Moderna. Usos de la carta $y$ de la correspondencia entre el manuscrito y el impreso, Universidad Complutense, Madrid, 2005a (Cuadernos de Historia Moderna. Anejos, IV).

BouZA, Fernando, El libro y el cetro. La Biblioteca de Felipe IV en la Torre Alta del Alcázar de Madrid, Salamanca, Instituto de Historia del Libro y de la Lectura, $2005 b$.

BouZA, Fernando, Papeles y opinión. Políticas de publicación en el Siglo de Oro, CSIC, Madrid, 2008.

BouzA, Fernando, Hétérographies. Formes de l'écrit au Siècle d'Or espagnol, Casa de Velázquez, Madrid, 2010.

Briggs, Asa y Burke, Peter, De Gutenberg a Internet. Una historia social de los medios de comunicación, Taurus, Madrid, 2002; ed. orig. A Social History of the Media. From Gutenberg to the Internet, Polity Press, Cambridge, 2001.

Burgos Rincón, Javier, «La imprenta barcelonesa en el tiempo del Quijote», en Carme Riera, ed., El «Quijote» y Barcelona, 2005, pp. 93-105.

Castillo Gómez, Antonio, Escrituras y escribientes. Prácticas de la cultura escrita en una ciudad del Renacimiento, Gobierno de Canarias-Fundación de Enseñanza Superior a Distancia (UNED), Las Palmas de Gran Canaria, 1997.

Castillo Gómez, Antonio, «La fortuna de lo escrito. Funciones y espacios de la razón gráfica (siglos XV-XVII)», Bulletin Hispanique, 100, 2 (1998), pp. 343-381.

CAstillo Gómez, Antonio, comp., Escribir y leer en el siglo de Cervantes, Gedisa, Barcelona, 1999a. 
Castillo Gómez, Antonio, «“Amanecieron en todas las partes públicas”. Un viaje al país de las denuncias», en A. Castillo Gómez, comp., Escribir y leer, 1999b, pp. 143-191.

CASTILlo GómEZ, Antonio, «Artificios epigráficos. Lecturas emblemáticas del escribir monumental en la ciudad del Siglo de Oro», en Víctor Mínguez, ed., Del libro de emblemas a la ciudad simbólica. Actas del III Simposio internacional de Emblemática hispánica, Universitat Jaume I, Castellón de la Plana, 2000a, I, pp. 151-168.

CASTILlo GómEZ, Antonio, "“Hablen cartas y callen barbas”. Escritura y sociedad en el Siglo de Oro», Historiar, 4 (2000b), pp. 116-127.

Castillo Gómez, Antonio, «Leer en comunidad. Libro y espiritualidad en la España del Barroco», Via Spiritus, 7 (2000c), pp. 99-122.

CASTILlo Gómez, Antonio, «Entre le public et le privé. Strategies de l'écrit dans l'Espagne du Siècle d'Or», Annales. Historie, Sciences Sociales, 56, $4-5$ (2001a), pp. 803-829.

CASTILlo GómeZ, Antonio, «La escritura representada. Imágenes de lo escrito en la obra de Cervantes», en A. Bernat Vistarini, ed., Volver a Cervantes, I, 2001b, pp. 311-325.

CASTILlo Gómez, Antonio, «"No pasando por ello como gato sobre brasas". Leer y anotar en la España del Siglo de Oro», Leituras. Revista da Biblioteca Nacional, 9-10 (20012002), pp. 99-121.

CASTillo Gómez, Antonio, «"Del donoso y grande escrutinio”. La lectura áurea entre la norma y la transgresión», en A. Castillo Gómez, ed., Libro y lectura en la Península Ibérica y América (siglos XIII a XVIII), Junta de Castilla y León: Consejería de Cultura y Turismo, Valladolid, 2003a, pp. 107-129.

CASTILlo Gómez, Antonio, «Del tratado a la práctica. La escritura epistolar en la Época Moderna», en Carlos Sáez y A. Castillo Gómez, eds., La correspondencia en la historia. Modelos y prácticas de la escritura epistolar. Actas del VI Congreso Internacional de Historia de la Cultura Escrita, Calambur, Madrid, 2003b, I, pp. 79-107.

CAStillo Gómez, Antonio, «"Aunque sean los papeles rotos de las calles”. Cultura escrita y sociedad en El Quijote», Revista de Educación, número extraordinario: El «Quijote» y la educación, coord. Gabriel Janer Manila (2004), pp. 67-76.

CAStillo Gómez, Antonio, «Leer en la calle. Coplas, avisos y panfletos áureos», Literatura: teoría, historia, crítica, 7 (2005a), pp. 15-43.

CASTILLO GómEZ, Antonio, «"El mejor retrato de cada uno”. La materialidad de la escritura epistolar en la sociedad hispana de los siglos XVI y XVII», Hispania, LXV/3, 221 (2005b), pp. 849-877.

Castillo Gómez, Antonio, «Delinquir escribiendo. Escrituras infamantes y represión inquisitorial en los Siglos de Oro», en Manuel Casado Arboniés, Antonio Castillo Gómez, Paulina Numhauser y Emilio Sola, eds., Escrituras silenciadas en la época de Cervantes, Servicio de Publicaciones: Universidad de Alcalá, Alcalá de Henares, 2006a, pp. 283-2986.

CASTILlo Gómez, Antonio, Entre la pluma y la pared. Una historia social de la escritura en los Siglos de Oro, Akal, Madrid, $2006 b$.

CAstillo Gómez, Antonio, «Maestros, estudiantes y copistas varios. Escribir a mano en los primeros tiempos de la Universidad de Alcalá», en Gian Paolo Brizzi y Maria Gioia Tavoni (eds.), Dalla pecia all'e-book. Libri per l'Università: stampa, editoria, circolazione e lettura. Atti del convengo internzionale di studi, Bologna, 21-25 ottobre 2008, Bolonia, Edizioni CLUEB, 2008, pp. 177-189.

CAstillo Gómez, Antonio, «A la vista de todos. Usos gráficos de la escritura expuesta en la España altomoderna», Scripta. An Internacional Journal of Codicology and Palaeography, 2, 2009a, pp. 73-90.

CASTILlo GÓMEZ, Antonio, «La letra en la pared. Usos y funciones de la escritura expuesta en el Siglo de Oro», en Manuel F. Fernández, Carlos Alberto González y Natalia Mai- 
llard (comps.), Testigo del tiempo, memoria del universo. Cultura escrita y sociedad en el mundo ibérico (siglos XV-XVIII), Ediciones Rubeo, Barcelona, 2009b, pp. 581-602.

CAstillo Gómez, Antonio, «Panfletos, coplas y libelos injuriosos. Palabras silenciadas en el Siglo de Oro», en Manuel Peña Díaz (ed.), Las Españas que (no) pudieron ser. Herejias, exilios y otras conciencias (siglos XVI-XX), Universidad de Huelva, Huelva, 2009c, pp. 59-73.

CAstillo Gómez, Antonio, «Desde el muro. formas y mensajes de la escritura expuesta en la ciudad altomoderna», en Gemma Puigvert y Carme de la Monta (eds.), La investigación en Humanidades, Biblioteca Nueva, Madrid, 2010, pp. 91-110.

CAstro, Américo, «Los prólogos al Quijote», Revista de Filología Hispánica, III (1941), pp. 314-338; reimpr. en Hacia Cervantes, Taurus, Madrid, 1957; 1967³, pp. 262-301.

CASTRO, Américo, «La palabra escrita y el Quijote», Asomante, 3 (1947); reimp. en Hacia Cervantes, pp. 292-324; ahora en El pensamiento de Cervantes y otros estudios cervantinos, ed. José Miranda, Trotta, Madrid, 2002 (Obra reunida, I).

CÁTEDRA, Pedro M., Imprenta y lecturas en la Baeza del siglo XVI, Seminario de Estudios Medievales y Renacentistas (SEMYR): Universidad de Salamanca, Salamanca, 2002a.

CÁTEDRA, Pedro M., Invención, difusión y recepción de la literatura popular impresa (siglo $X V I)$, Editora Regional de Extremadura, Badajoz. $2002 b$.

CÁtedra, Pedro M., Nobleza y lectura en tiempos de Felipe II. La biblioteca de don Alonso Osorio, Marqués de Astorga, Junta de Castilla y León, Valladolid, 2002c.

CÁtedra, Pedro M., «Censura político-administrativa de la literatura popular impresa (siglo XVI)», en Pierre Civil, coord., Siglos dorados. Homenaje a Augustin Redondo, Madrid: Castalia, 2004, I, 251-269.

CÁtedra, Pedro M., dir., La literatura popular impresa en España y en la América Colonial. Formas \& temas, géneros, funciones, difusión, historia y teoría, edición al cuidado de Eva Belén Castro Carbajal, Laura Mier, Lauro Puerto Moro y María Sánchez Pérez, Seminario de Estudios Medievales y Renacentistas-Instituto de Historia del Libro y de la Lectura, Salamanca, 2006.

CÁtedra, Pedro M. y RoJo, Anastasio, Bibliotecas y lecturas de mujeres. Siglo XVI, Instituto de Historia del Libro y de la Lectura, Salamanca, 2004.

CÁtedra, Pedro M., El sueño caballeresco. De la caballería de papel al sueño real de Don Quijote, Abada, Madrid, 2007.

Cayuela, Anne, Le paratexte au Siècle d'Or. Prose romanesque, livres et lecteurs en Espagne du XVIIe siècle, Droz, Ginebra, 1996.

Cayuela, Anne, Alonso Pérez Montalbán. Un librero en el Madrid de los Austrias, Calambur, Madrid, 2005.

CERDA, Juan de la, Vida política de todos los estados de mujeres, Juan Gracián, Alcalá de Henares, 1599.

Cervantes, Miguel de, Don Quijote de la Mancha, edición del IV Centenario, edición y notas Francisco Rico, Real Academia Española-Asociación de Academias de la Lengua Española-Alfagurara, Madrid, 2004a.

Cervantes, Miguel de, Entremeses, ed. Nicholas Spadaccini, Cátedra, Madrid, 2004b, $16 .^{\mathrm{a}}$ ed.

Cervantes, Miguel de, Don Quijote de la Mancha, edición del Instituto Cervantes dirigida por Francisco Rico, Galaxia Gutenberg-Círculo de Lectores-Centro para la Edición de los Clásicos Españoles, Barcelona, 2005.

CHARTIER, Roger, «Ocio y sociabilidad en voz alta en la Europa moderna», en R. Chartier, El mundo como representación. Estudios sobre historia cultural, Gedisa, Barcelona, 1992, pp. 121-144; ed. orig. "Loisir et sociabilité: lire à haute voix dans l'Europe moderne», Littératures classiques, 12 (1990), pp. 127-147. 
CHARTIER, Roger, Pluma de ganso, libro de letras, ojo viajero, Universidad Iberoamericana: Departamento de Historia, México, 1997.

CHARTIER, Roger, Publishing Drama in Early Modern Europe, University of Toronto Press, Toronto, 1999.

CHARTIER, Roger, «El manuscrito en la era de la imprenta», en R. Chartier, Las revoluciones de la cultura escrita. Diálogo e intervenciones, Gedisa, Barcelona, 2000, pp. 137-156; ed. orig. «Le manuscrit à l'âge de l'imprimé. Lectures et réflexions», Lettre clandestine, 7 (1998), pp. 175-193.

CHARTIER, Roger, Do palco à pagina. Publicar teatro e ler romances na época moderna (séculos XVI-XVIII), Casa da Palabra, Río de Janeiro, 2002a.

Chartier, Roger, «Dom Quixote na tipografia», en R. Chartier, Os desafios da escrita, Editoria da UNESP, São Paulo, 2002b, pp. 33-60. Otras versiones de este artículo en R. Chartier, Inscribir y borrar, 2006, pp. 61-87, y en J. M. Lucía Megías, ed., Imprenta, libros y lectura, 2006, pp. 481-498.

CHARTIER, Roger, «El concepto del lector moderno», en V. Infantes, F. Lopez y J.-F. Botrel, dirs., Historia de la edición y de la lectura en España, 2003, pp. 142-150.

CHARTIER, Roger, «Écriture et mémoire. Le "librillo" de Cardenio», en Louisse BénatTachot y Jean Vilar, dirs., La question du lecteur. XXXe congrès de la Société des hispanistes français, mai 2003, Ambassade d'Espagne-Presses universitaires de Marnela-Vallée, Marne-la-Vallée, 2004a; trad. esp. «Escritura y memoria. El "librillo" de Cardenio», en R. Chartier, Inscribir y borrar, 2006, pp. 39-60.

CHARTIER, Roger, «La Europa castellana durante el tiempo del Quijote», en A. Feros y J. Gelabert, dirs., España en tiempos del Quijote, 2004b, pp. 129-158.

CHARTIER, Roger, «Escritura, oralidad e imagen en el Siglo de Oro», en R. Chartier, El presente del pasado. Escritura de la historia, historia de lo escrito, Universidad Iberoamericana, México, 2005a, pp. 117-131.

CHARTIER, Roger, «Leer en los tiempos de Covarrubias», en R. Chartier, El presente del pasado, 2005b, pp. 89-115.

CHARTIER, Roger, Inscribir y borrar. Cultura escrita y literatura (siglos XI-XVIII), Katz, Buenos Aires, 2006.

CHEVAlIER, Maxime, Lectura y lectores en la España del siglo XVI y XVII, Turner, Madrid, 1976.

Chevalier, Maxime, «Lectura en voz alta y novela de caballerías. A propósito de Quijote I:32», Boletín de la Real Academia Española, 79 (1999), 55-65.

DADSON, Trevor J., Libros, lectores y lecturas. Estudios sobre bibliotecas particular españolas del Siglo de Oro, Arco/Libros, Madrid, 1998.

De l'alphabétisation aux circuits du livre en Espagne, XVIe-XIXe siècles, Éditions du CNRS, París, 1987.

DíAz Migoyo, Gonzalo, «Antes de leer el Quijote: impertinencia prologal y deformación lectora», en A. Bernat Vistarini, ed., Volver a Cervantes, I, 2001, pp. 539-543.

Dopico BLACK, Georgina, «La historia del ingenioso hidalgo Miguel de Cervantes», en A. Feros y J. Gelabert, dirs., España en tiempos del Quijote, 2004, pp. 23-40.

EgIDO, Aurora, La voz de las letras en el Siglo de Oro, Abada, Madrid, 2003.

EgIDO, Aurora, "Los discretos prólogos de "El Quijote"», en B. López de Mariscal y J. Farré, eds., Cuatrocientos años, 2004, pp. 25-37.

EISENBERG, Daniel, «¿Tenía Cervantes una biblioteca?», en D. Eisenberg, Estudios Cervantinos, Sirmio, Barcelona, 1991, pp. 11-36; ed. orig. «Did Cervantes have a library?», en John S. Miletiche, ed., Hispanic studies in honor of Alan D. Deyermond: A North American tribute, Hispanic Seminary of Medieval Studies, Madison, 1986, pp. 93-106. 
Eisenberg, Daniel y StagG, Geoffrey, eds., «Entremés de los romances», Cervantes: Bulletin of the Cervantes Society of America, XXII, 2 (2002), pp. 151-174.

Elliot, John H., El Conde-duque de Olivares. El político en una época de decadencia, Crítica, Barcelona, 1990; ed. orig. The Count-Duke of Olivares. The Statesman in an Age of Decline, Yale University, New Haven-Londres, 1986.

ESTRUCH TOBELla, Joan, «Cervantes, instrumento de propaganda política en la coyuntura 1640-1650», Cervantes: Bulletin of the Cervantes Society of America, 12, 1 (1992), pp.111-117.

Feros, Antonio y Gelabert, Juan Eloy, dirs., España en tiempos del Quijote, Taurus, Madrid, 2004.

Foucault, Michel, Las palabras y las cosas. Una arqueología de las ciencias humanas, Siglo XXI, México, 1999 (1968); ed. orig., Les nots et les choses, une archéologie des sciences humaines, Paris, Gallimard, 1968.

FrenK, Margit, Entre la voz y el silencio (La lectura en tiempos de Cervantes), Centro de Estudios Cervantinos, Alcalá de Henares, 1997; reed. FCE, México, 2005.

FRENK, Margit, «Las formas de leer, la oralidad y la memoria», en V. Infantes, F. López y J.-F. Botrel, dirs., Historia de la edición y de la lectura en España, 2003, pp. 151158.

Frenk, Margit, «Oralidad, escritura, lectura», en M. de Cervantes, Don Quijote de la Mancha, 2004, pp. 1138-1144.

Fuentes, Carlos, Cervantes o la crítica de la lectura, Joaquín Mortiz, México, 1976; reed. Centro de Estudios Cervantinos, Alcalá de Henares, 1994.

Galende Díaz, Juan Carlos, «Cultura escrita en época cervantina», Cuadernos de Investigación histórica, 22 (2005), pp. 173-190.

GARAU, Jaume, «Notas sobre la predicación en el Quijote», en A. Bernat Vistarini, ed., Volver a Cervantes, I, 2001, pp. 577-582.

García Aguilar, Ignacio, Poesía y edición en el Siglo de Oro, Calambur, Madrid, 2009.

García de EnTERría, María Cruz, Sociedad y poesía de cordel en el Barroco, Taurus, Madrid, 1973.

García DE EnTERRía, María Cruz, «¿Lecturas populares en tiempos de Cervantes?», en Antonio Castillo Gómez (comp.), Escribir y leer, 1999, 345-362.

García de Enterría, M. ${ }^{a}$ Cruz y Cordón Mesa, Alicia, ed., Actas del IV Congreso Internacional de la Asociación Internacional Siglo de Oro (AISO) (Alcalá de Henares, 22-27 de julio de 1996), Universidad de Alcalá: Servicio de Publicaciones, Alcalá de Henares, 1998, 2 t.

GarCía MartíneZ, Antonio Claret, La palabra transformada. Oralidad y cultura escrita en la predicación de los siglos XV al XVII, Universidad de Huelva, Huelva, 2006.

Garza Merino, Sonia, Manuscritos e imprenta, Tesis Doctoral inédita, Universidad de Alcalá, Alcalá de Henares, 2005.

GARZA Merino, Sonia, «Vida de San Jerónimo: el texto en proceso de construcción», Edad de Oro, 28, 2009, pp. 105-142.

Gascón, Jesús, ed., La rebelión de las palabras. Sátiras y oposición política en Aragón (1590-1626), Prensas Universitarias de Zaragoza, Zaragoza, 2003.

Geal, François, Figures de la bibliothèque dans l'imaginaire espagnol du Siècle d'Or, Champien-Slatrine, París, 1999.

Gimeno Blay, Francisco M., «Aprender a escribir en la Península Ibérica: de la Edad Media al Renacimiento», en Armando Petrucci y Francisco M. Gimeno Blay, eds., Escribir $y$ leer en Occidente, Universitat de València, Valencia, 1995, pp. 125-144. 
Gimeno Blay, Francisco M., «Aprender a escribir en el Antiguo Régimen», en Agustín Escolano, dir, Historia ilustrada del libro escolar en España. Del Antiguo Régimen a la Segunda República, Fundación Germán Sánchez Ruipérez, Madrid, 1997, pp. 291-314.

Gimeno Blay, Francisco M., «“... missivas, mensageras, familiares...”. Instrumentos de comunicación y de gobierno en la España del Quinientos», en A. Castillo, comp., Escribir y leer, 1999, pp. 193-209.

Gimeno Blay, Francisco M., Admiradas mayúsculas. La recuperación de los modelos gráficos romanos, Instituto de Historia del Libro y de la Lectura, Salamanca, 2005.

GonZÁlez PALENCIA, Ángel, «El curandero morisco del siglo XVI, Román Ramírez», Boletín de la Real Academia Española, XVI (1929-1930), pp. 199-222, y XVII (1930), pp. 247-274; reimp. en su libro Historias y leyendas. Estudios literarios, CSIC, Madrid, 1942, pp. 215-284.

GonZÁlez SÁncheZ, Carlos Alberto, «El libro y la Carrera de Indias: registro de ida de navíos», Archivos Hispalenses, 220 (1989), pp. 93-103.

GonzÁlez SÁnchez, Carlos Alberto, Los mundos del libro. Medios de comunicación de la cultura occidental en las Indias de los siglos XVI y XVII, Universidad de SevillaDiputación de Sevilla, Sevilla, 1999.

GONZÁLEZ SÁNCHEZ, Carlos Alberto, «"Lection espiritual”. Lectores y lectura en los libros ascético-espirituales de la Contrarreforma», en Carlos A. González Sánchez y Enriqueta Vila Vilar, coords., Grafías del imaginario. Representaciones culturales en España y América (siglos XVI-XVIII), FCE, México, 2003, pp. 272-300.

Gonzalo SÁnchez-Molero, José Luis, Regia Bibliotheca. El libro en la corte española de Carlos V, Editora Regional de Extremadura, Mérida, 2004, 2 v.

GRIFFIN, Clive, «Un curioso inventario de libros de 1528», en M. ${ }^{a}$ Luisa López Vidriero y Pedro M. Cátedra, eds., El libro antiguo español. Actas del primer Coloquio Internacional (Madrid, 18 al 20 de diciembre de 1986), Ediciones Universidad de SalamancaBiblioteca Nacional de Madrid-Sociedad española de Historia del Libro, Salamanca, 1988, pp. 189-224.

GRIFFIN, Clive, «El inventario del almacén de libros del impresor Juan Cromberger: Sevilla, 1540», en M. ${ }^{a}$ Luisa López Vidriero y Pedro M. Cátedra, eds., El libro antiguo español, IV. Coleccionismo y Bibliotecas (Siglos XV-XVIII), Ediciones Universidad de Salamanca-Patrimonio Nacional-Sociedad española de Historia del Libro, 1998, pp. 257-373.

GrIFFIn, Clive, Oficiales de Imprenta, Herejía o Inquisición en la España del siglo XVI, Ollero y Ramos, Madrid, 2009; ed. orig., Journeymen-Printers, Heresy, and the Inquisition in Sixteenth-Century Spain, Oxford University Press, Oxford-Nueva York, 2005.

GrILLI, Giuseppe, «Don Quijote escribe cartas», en Pierre Civil, coord., Siglos dorados. Homenaje a Augustin Redondo, Castalia, Madrid, 2004, I, pp. 613-627.

GRUPO PRINQUEPS 1605, «La primera edición del Quijote. Avances críticos para la interpretación y análisis del silencio tipográfico», Edad de Oro, XXVIII, 2009, pp. 285-340.

HARVEY, Leonard P., «Oral Composition and the Performance of Novels of Chivalry in Spain», en Joseph Dugan, ed., Oral Literature. Seven Essays, Scotish Academic Press, Edimburgo-Londres, 1975, pp. 84-100.

Herpoel, Sonja, A la zaga de Santa Teresa: Autobiografias por mandato, Rodopi, Ámsterdam-Atlanta, 1999.

IfFLAND, James, «Don Quijote dentro de la Galaxia Gutenberg (reflexiones sobre Cervantes y la cultura tipográfica)», Journal of Hispanic Philology, XIV (1989), pp. 23-41.

IfFlAND, James, De fiestas y aguafiestas. Risa, locura e ideología en Cervantes y Avellaneda, Iberoamericana, Madrid, 1999. 
IgLESIAS, Carmen, coord., El mundo que vivió Cervantes, Catálogo de la exposición celebrada en el Centro Cultural de la Villa de Madrid del 13 de octubre de 2005 al 8 de enero de 2006, Sociedad Estatal de Conmemoraciones Culturales, Madrid, 2005.

IMPERIALE, Louis, «Las lagunas en las lecturas que hizo don Quijote», en A. Bernat Vistarini, ed., Volver a Cervantes, I, 2001, pp. 491-498.

INFANTES, Víctor, «De la cartilla al libro», en La culture des élites espagnoles à l'Époque Moderne, número monográfico de Bulletin Hispanique, 97 (1995), pp. 33-66.

INFANTES, Víctor, De las primeras letras. Cartillas españolas para enseñar a leer de los siglos XV y XVI, Ediciones Universidad de Salamanca, Salamanca, 1998.

INFANTES, Víctor, «Ristras de papeles y rimas de libretes. Las lecturas populares en el cambio de siglo», en Pedro Ruiz Pérez y Klaus Wagner, eds., La cultura en Andalucía. Vida, memoria y escritura en torno a 1600. Estepa, Ayuntamiento de Estepa, 2001, pp. 129-142.

INFANTES, Víctor, «Don Quijote entró en la imprenta y se convirtió en libro», en Jesús Menéndez Peláez, ed., El «Quijote», 1605-2005, IV Centenario, 2005a, pp. 191-202.

INFANTES, Víctor, «La librería de Don Quijote y los libros de Cervantes (I, 6)», en Christophe Couderc y Benoît Pellestrandi, eds., "Por discreto y por amigo». Mélanges offerts à Jean Canavaggio, Casa de Velázquez, Madrid, 2005b, pp. 79-92.

INFANTES, Víctor, Del libro áureo, Calambur, Madrid, 2006.

INFANTES, Víctor, La trama impresa de "Celestina». Ediciones, libros y autógrafos de Fernando de Rojas, Visor, Madrid, 2010.

InFANTES, Víctor; LOPEZ, François y Botrel, Jean-François Botrel, dirs., Historia de la edición y de la lectura en España, 1472-1914, Fundación Germán Sánchez Ruipérez, Madrid, 2003.

Infantes, Víctor y Martínez Pereira, Ana, «La aventura cultural de aprender a leer y a escribir en tiempos de Calderón (1600-1681)», en María Gómez y Patiño, coord., Calderón: una lectura desde el siglo XXI, Instituto Alicantino de Cultura Juan GilAlbert, Alicante, 2000, pp. 131-159.

Infantes, Víctor y MARTínez PereirA, Ana, De las primeras letras. Cartillas españolas para aprender a leer del siglo XVII y XVIII, Ediciones Universidad de Salamanca, Salamanca, 2003, 2 vols.

Jauralde Pou, Pablo, «El estilo cervantino», en Cervantes, Centro de Estudios Cervantinos, Alcalá de Henares, 1995, pp. 137-154.

Jover Zamora, José María, dir., El siglo del Quijote (1580-1680), en Historia de España. Menéndez Pidal, XXVI, Espasa-Calpe, Madrid, 1986, 2v.

LÁzaro CArreter, Fernando, «Las voces del "Quijote"», en M. de Cervantes, Don Quijote de la Mancha, 2005, pp. XXIII-XL.

LEONARD, Irving A., Los libros del conquistador (1949), FCE, México, 1979.

LoBATO, María Luisa, «El Quijote en las mascaradas populares del siglo XVII», en Kurt Reichenberg, ed., Estudios dedicados a Cervantes en la víspera de su centenario, Reichenberg, Kassel, 1992, II, pp. 577-604.

LOPEZ, François, Hacia una historia de la lectura, Societat Bibliogràfica Valenciana «Jerònima Galés», Valencia, 2005.

LóPez de Mariscal, Blanca y FARré, Judith, eds., Cuatrocientos años del ingenioso hidalgo. Colección de Quijotes en la Biblioteca Cervantina y cuatro estudios, Cátedra Alfonso Reyes (ITESM)-FCE, México, 2004a.

LÓPEZ DE MARISCAL, Blanca y FARRÉ, Judith, «El Quijote, un acercamiento a las formas de apropiación», en B. López de Mariscal y J. Farré, eds., Cuatrocientos años, 2004b, pp. 25-37. 
LÓPEZ ESTRADA, Francisco, «La función de la biblioteca en el Quijote», en De libros y bibliotecas. Homenaje a Rocío Caracuel, Universidad de Sevilla, Sevilla, 1994, pp. 193-200.

Lucía Megías, José Manuel, Imprenta y libros de caballerías, Ollero y Ramos, Madrid, 2001.

Lucía Megías, José Manuel, De los libros de caballerías manuscritos al «Quijote», Sial, Madrid, 2003.

Lucía Megías, José Manuel, Aqui se imprimen libros. La imprenta en la época del Quijote, Ollero y Ramos-Imprenta Artesanal, Madrid, 2005.

Lucía Megías, José Manuel, ed., Imprenta, libros y lectura en la España del «Quijote», Ayuntamiento de Madrid: Imprenta Artesanal, Madrid, 2006 .

Lucía Megías, José Manuel, Leer el "Quijote» en imágenes. Hacia una teoría de los modelos iconográficos, Calambur, Madrid, $2006 b$.

Lucía Megías, José Manuel y Vargas Díaz-Toledo, Aurelio, «Don Quijote en América: Pausa, 1607 (facsímil y edición)», Literatura: teoría, historia, crítica, 7 (2005), pp. 203-244.

Luengo PaCheCo, Ricardo, Libros y lectores en Plasencia (siglos XVI-XVIII), Cáceres, Universidad de Extremadura, 2002.

LunA, Lola, Leyendo como una mujer la imagen de la mujer, Anthropos-Junta de Andalucía: Instituto Andaluz de la Mujer, Barcelona-Sevilla, 1996.

Manguel, Alberto, «Don Quijote, autor de Cervantes», Estudios Públicos, 100 (2005), pp. $43-50$.

ManN, Thomas, Viajes por mar con don Quijote, RqueR, Barcelona, 2005; ed. orig. Meerfahrt mit don Quijote, Bermann-Fischer Verlag AB, Estocolmo, 1945.

Marchant Rivera, A., Literatura e historia de la cultura escrita. Prácticas bibliófilas y escriturarias en «El Quijote» de Cervantes, Universidad de Málaga, Málaga, 2003.

MARÍn PINA, M. ${ }^{a}$ Carmen, «Lectores y lecturas caballerescas en el Quijote», en Actas del III Coloquio Internacional de la Asociación de Cervantistas, Alcalá de Henares, 12-16 de noviembre de 1990, Anthropos, Barcelona, 1993, pp. 265-273.

MARín PINA, M. ${ }^{a}$ Carmen, «Los lectores de los libros de caballerías», en C. Alvar y J. M. Lucía Megías, eds., El delirio y la razón, 2005, pp. 38-47.

MARSA, María, La imprenta en los Siglos de Oro, Ediciones del Laberinto, Madrid, 2001.

MARTín, Francisco J., «Los prólogos del Quijote: la consagración de un género», Cervantes: Bulletin of the Cervantes Society of America 13, 1 (1993), pp. 77-87.

Martín, Henri-Jean, Historia y poderes del escrito, Trea, Gijón, 1999, ed. orig. Histoire et pouvoirs de l'ecrit, Albin Michel, París, 1996.

MARTín ABAD, Julián, Los libros impresos antiguos, España, Universidad de Valladolid, Secretariado de Publicaciones e Intercambio editorial, Valladolid, 2004.

MARTín BAÑos, Pedro, El arte epistolar en el Renacimiento europeo, 1400-1600, Universidad de Deusto, Bilbao, 2005.

MARTín Morán, José Manuel, «Cervantes: el juglar zurdo de la era Gutenberg», Cervantes: Bulletin of the Cervantes Society of America, XVII, 1 (1997a), pp. 122-144.

MARTín MorÁn, José Manuel, «Don Quijote en la encrucijada: oralidad/escritura», Nueva Revista de Filología Hispánica, XLV, 2 (1997b), pp. 337-368.

MARTín Morán, José Manuel, «Autoridad y autoría en el Quijote», en M. ${ }^{a}$ Cruz García de Enterría y A. Cordón Mesa, ed., Actas del IV Congreso, 1998, 2, pp. 1005-1016.

Martín Morán, José Manuel, Autoridad, palabra y lectura en el «Quijote», Mercurio, Vercelli, 2008.

Martínez Mata, Emilio, Cervantes comenta el «Quijote», Cátedra, Madrid, 2008. 
Martínez Mata, Emilio, «El poder de la imagen en los textos del Siglo de Oro: el caso del Quijote», Edad de Oro, XXVIII (2009), pp. 197-236.

MARTínez Pereira, Ana, Manuales de escritura de los Siglos de Oro. Repertorio crítico y analítico de obras manuscritas e impresas, Editora Regional de Extremadura, Mérida, 2006.

McLuHAn, Marshall, La galaxia Gutenberg. Génesis del «Homo typographicus», Galaxia Gutenberg-Círculo de Lectores, Barcelona, 1993; ed. orig. The Gutenberg Galaxy, Toronto, University of Toronto Press, 1962.

Menéndez Peláez, Jesús, coord., El «Quijote», 1605-2006. IV Centenario, Ayuntamiento de Gijón: Fundación Municipal de Cultura, Educación y Universidad-Principado de Asturias: Consejería de Cultura, Comunicación social y Turismo-KRK Ediciones, Oviedo, 2005.

MenÉndez Pelayo, Marcelino, «Cultura literaria de Miguel de Cervantes y elaboración del Quijote», en Edición Nacional de las Obras Completas Menéndez Pelayo, dir. Miguel Artigas, CSIC, Madrid, 1941, VI, pp. 323-356; reed. en Cultura literaria, Catálogo de la exposición celebrada en la Biblioteca Nacional de Madrid con motivo del 450 aniversario del nacimiento de Cervantes, Centro de Estudios Cervantinos, Alcalá de Henares, 1997, pp. 7-25.

MeXía, Pedro, Silva de varia lección, ed. Antonio Castro, Cátedra, Madrid, 1989.

Moll, Jaime, De la imprenta al lector. Estudios sobre el libro español de los siglos XVI al XVIII, Arco/Libros, Madrid, 1994.

Moner, Michel, Cervantes conteur. Écrits et paroles, Casa de Velázquez, Madrid, 1989.

Montero, Juan y Ruiz Pérez, Pedro, «El libro en el Siglo de Oro. Estado de la investigación (1980-2005)», Etiopicas, 2 (2006), pp. 15-108.

Montero Reguera, José, «La recepción del Quijote en Hispanoamérica (siglos XVII al XIX)», Cuadernos Hispanoamericanos, 500 (1992), pp. 133-140.

MONTERo Reguera, José, El «Quijote» durante cuatro siglos: lecturas y lectores, Universidad de Valladolid: Secretariado de Publicaciones e Intercambio Editorial, Valladolid, 2005.

Montero Reguera, José, «El Quijote en Hispanoamérica», en Héctor Brioso Santos, Cervantes y América, Marcial Pons, Madrid, 2006a, pp. 317-343.

Montero Reguera, José, «El Quijote en 1640: historia, política y algo de literatura», Edad de Oro, XXV (2006b), pp. 437-446.

MuRILlo, Luis Andrés, «Cervantes y el Entremés de los romances», en A. D. Kossof et al., eds., Actas del VIII Congreso de la Asociación Internacional de Hispanistas, Istmo, Madrid, 1986, II, pp. 353-357.

Nalle, Sara T., «Literacy and culture in Early Modern Castille», Past \& Present, 125, 1989, pp. 65-96.

NAVARRO Bonilla, Diego, «"Por y contra la escritura": las causas judiciales de la cultura escrita», en Manuel Casado Arboniés, Antonio Castillo Gómez, Paulina Numhauser y Emilio Sola, eds., Escrituras silenciadas en la época de Cervantes, Servicio de Publicaciones: Universidad de Alcalá, Alcalá de Henares, 2006, pp. 113-131.

NAVARRo Bonilla, Diego, "De civitate librorum: apuntes para una historia de la cultura escrita en la República Literaria de Saavedra Fajardo (1612)», Bulletin Hispanique, (104), 2 (2002), pp. 731-752.

NaVARro Bonilla, Diego, Del corazón a la pluma. Archivos y papeles privados femeninos en la Edad Moderna, Ediciones Universidad de Salamanca, Salamanca, 2004.

ONG, Walter, Oralidad y escritura. Tecnologías de la palabra, FCE, México, 1993; ed. orig. Orality and Literacy. The Technologizing of the Word, Methuen \& Co. Ltd., Londres, 1982.

Paz Gago, José M. a , «Oralidad, escritura y visualidad en el Quijote», en M. ${ }^{a}$ Cruz García de Enterría y A. Cordón Mesa, ed., Actas del IV Congreso, 1998, 2, pp. 1169-1186. 
PAZ GAGO, José M. a, «"Una de las más raras [...] novedades que imaginarse pueden”. Las tecnologías en el Quijote», en C. Alvar y J. M. Lucía Megías, eds., El delirio y la razón, 2005, pp. 48-69.

Pedrosa, José Manuel, Tradición oral y escrituras poéticas en los Siglos de Oro, Sendoa, Oiartzun, 1999.

Pedrosa, José Manuel, El cuento popular en los Siglos de Oro, Ediciones del Laberinto, Madrid, 2004.

PeÑa DíAZ, Manuel, Cataluña en el Renacimiento: libros y lenguas, Milenio, Lleida, 1996.

PeÑa DíAz, Manuel, El laberinto de los libros. Historia cultural de la Barcelona del Quinientos, Fundación Germán Sánchez Ruipérez, Madrid, 1997.

PeÑa DíAz, Manuel, «El espejo de los libros: lecturas y lectores en la España del Siglo de Oro», en M. Peña Díaz, Pedro Ruiz Pérez y Julián Solana Pujalte, coord., La cultura del libro en la Edad Moderna. Andalucía y América, Universidad de Córdoba: Servicio de Publicaciones, Córdoba, 2001, pp. 145-158.

PeÑa DíAZ, Manuel, «Libros permitidos, lecturas prohibidas (siglos XVI-XVII)», en Gloria A. Franco Rubio, coord., De mentalidades y formas culturales en la Edad Moderna, Universidad Complutense de Madrid, Madrid, 2002 (Cuadernos de Historia Moderna. Anejos, I), pp. 85-101.

PeÑa DíAZ, Manuel, «El libro bajo sospecha (siglos XVI-XVII)», en Pedro M. Cátedra y M. ${ }^{a}$ Luisa López Vidriero, dirs., La memoria de los libros. Estudios sobre la historia del escrito y de la lectura en Europa y América, ed. M. ${ }^{a}$ Isabel de Paiz Hernández, Instituto de Historia del Libro y de la Lectura, Salamanca, 2004, I, pp. 805-824.

PeÑa DíAZ, Manuel, «El "donoso y grande escrutinio" o las caras de la censura», Hispania, LXV/3, 221 (2005), pp. 939-956.

Peraita Huerta, Carmen, «Comercio de difuntos, ocio fatigoso de los estudios: Libros y prácticas lectoras de Quevedo», La Perinola: Revista de investigación quevediana, 7 (2003), pp. 271-295.

Peraita Huerta, Carmen, «Marginalizing Quevedo: Reading Notes and the Humanistic Persona», Variants. The Journal of the European Society for Textual Scholarship, 2/3 (2004), pp. 37-60.

PETRUCCI, Armando, «Storia e geografia delle culture scritte (dal seccolo XI al secolo XVIII)», en Alberto Asor Rosa (ed.), Letteratura italiana, II. Storia e Geografia, II: L'etá moderna, Einaudi, Turín, 1998, pp. 1193-1292.

Petrucci, Armando, «Leer en la Edad Media», en Armando Petrucci, Alfabetismo, escritura, sociedad, Gedisa, Barcelona, 1999, pp. 183-196, ed. orig., «Lire au moyen âge», Mélanges de l'École Française de Rome (Moyen âge- Temps módernes), 96 (1984), pp. 603-616.

PonTón, Gonzalo, Correspondencia. Los orígenes del arte epistolar en España, Biblioteca Nueva, Madrid, 2002.

Porqueras MAYO, Alberto, «En torno a los prólogos de Cervantes», en Manuel Criado del Val, ed., Cervantes: Su obra y su mundo. Actas del I Congreso Internacional sobre Cervantes, EDI-6, Madrid, 1981, pp. 75-84.

POUTRIN, Isabelle, Le voile et la plume. Autobiographie et sainteté féminine dans l'Espagne moderne, Casa de Velázquez, Madrid, 1995.

Prieto Bernabé, José Manuel, Lectura y lectores. La cultura del impreso en el Madrid del Siglo de Oro (1550-1650), Editora Regional de Extremadura, Mérida, 2004, 2 t.

PROFETI, Maria Grazia, «Escritura, compañías, destinatarios: un teatro de la ambigüedad», en Catherine Poupeney Hart, Alfredo Hermenegildo y César Oliva, coord., Cervantes y la puesta en escena de la sociedad de su tiempo (Actas del coloquio de Montreal, 1997), Universidad de Murcia, Murcia, 1999, pp. 55-75. 
Rey Castelao, Ofelia, Libros y lectura en Galicia. Siglos XVI-XIX, Xunta de Galicia, Santiago de Compostela, 2003.

Rial Costas, Benito, Producción y comercio del libro en Santiago (1501-1553), Calambur, Madrid, 2007.

Rico, Francisco, Breve biblioteca de autores españoles, Seix Barral, Barcelona, 1990.

Rico, Francisco, «Componedores y grafías en el Quijote de 1604 (sobre un libro de Robert M. Flores)», en Antonio Bernat Vistarini, ed., Actas del III Congreso Internacional de la Asociación de Cervantistas, Palma de Mallorca, Universitat de les Illes Balears, 1998, pp. 63-83.

Rico, Francisco, «Don Quijote, Madrid, 1604, en prensa», Bulletin Hispanique, CI, 2 (1999), pp. 415-434; reimp. en «El Quijote»: biografía de un libro, 1605-1005, Biblioteca Nacional, Madrid, 2005, pp. 49-75.

Rico, Francisco, dir., Imprenta y crítica textual en el Siglo de Oro, al cuidado de Pablo Andrés y Sonia Garza, Universidad de Valladolid-Centro para la Edición de los Clásicos Españoles, 2000.

Rico, Francisco, «A pie de imprentas. Páginas y noticias de Cervantes viejo», Bulletin Hispanique, CIV, 2 (2002a), pp. 673-702.

Rico, Francisco, «El Don Quijote sin Don Quijote», L'Erasmo. Bimestrale della civiltà europea, 10 (2002b), pp. 142-150.

Rico, Francisco, En torno al error. Copistas, tipógrafos, filologías, Centro para la Edición de los Clásicos Españoles, Madrid, 2004.

Rico, Francisco, «Historia del texto», en M. de Cervantes, Don Quijote de la Mancha, 2005a, pp. CCXXI-CCLXXVI.

Rico, Francisco, El texto del «Quijote». Preliminares a una ecdótica del Siglo de Oro, Destino-Centro para la Edición de los Clásicos españoles-Universidad de Valladolid, $2005 b$.

RIERA, Carme, ed., El «Quijote» y Barcelona, Ajuntament de Barcelona-Lunwerg, Barcelona, 2005.

RILEY, Edward C., «Don Quijote, del texto a la imagen», en E. Riley, La rara invención. Estudios sobre Cervantes y su posteridad literaria, Crítica, Barcelona, 2001, pp. 169-182; ed. original, «Don Quioxte: from Text to Icon», Cervantes, número especial (invierno de 1998), pp. 103-115.

RiQuer, Martín de, Para leer a Cervantes, El Acantilado, Barcelona, 2003 (1989).

Rivero Rodríguez, Manuel, La España de Don Quijote. Una viaje al Siglo de Oro, Alianza Editorial, Madrid, 2005.

Rodríguez, Juan Carlos, El escritor que compró su propio libro. Para leer "El Quijote», Debate, Barcelona, 2003.

RodríGuez CACHO, Lina, «La frustración del humanista escribiente en el siglo XVI: el caso de Antonio de Torquemada», Criticón, 44 (1988), pp. 61-73.

Rodríguez Marín, Francisco, El «Quijote» y Don Quijote en América, Librería de los Sucesores de Hernando, Madrid, 1911.

RodríGUEZ MARín, Francisco, «Quixotesco cartel de desafío fechado en el Toboso, año 1641» [1922], Estudios cervantinos, Atlas, Madrid, 1947, pp. 609-619.

Rueda Ramírez, Pedro J., Negocio e intercambio cultural: el comercio de libros con América en la carrera de Indias (siglo XVII), Diputación de Sevilla-Universidad de Sevilla-CSIC: Escuela de Estudios Hispano-Americanos, 2005.

RuIz Astiz, Javier, «Amenaza, burla y mofa contra el estamento nobiliario: libelos y pasquines en Navarra durante la Edad Moderna», en Manuel Rodríguez Rivero (coord.), Nobleza hispana, nobleza cristiana: la Orden de San Juan, Polifemo, Madrid, 2009a, pp. 299-326.

Ruiz Astiz, Javier, «Herramientas de transmisión comunitaria: libelos y pasquines en la Navarra moderna», Historia y comunicación social, 19 (2009b), pp. 87-110. 
RuIZ Astiz, Javier, Los desórdenes públicos y la violencia colectiva en la Navarra moderna (1512-1808), Universidad de Navarra, Pamplona, 2010, Tesis Doctoral inédita.

Ruiz PÉrez, Pedro, Libros y lecturas de un poeta humanista (Fernando de Herrera, 1534-1597). Catálogo bibliográfico por Ana Rojas Pérez, Universidad de Córdoba, Córdoba, 1997.

SaAvedra Fajardo, Diego de, República Literaria, edición de Jorge García López, Crítica, Barcelona, 2006.

Sacido Romero, Alberto, «Oralidad, escritura y dialogismo en el Quijote de 1605», Anales Cervantinos, XXXIII (1995-1997), pp. 39-60.

SARMATTI, Elisabetta, Le critiche ai libri di cavalleria nel Cinquecento spagnolo (con uno sguardo sul Seicento). Un'analisi testuale, Giardini Editori, Pisa, 1996.

SERES, Guillermo, «La defensa cervantina de la lectura», en B. López de Mariscal y J. Farré, eds., Cuatrocientos años, Cuatrocientos años, 2004, pp. 67-84.

SERES, Guillermo, «El Quijote como justificación ética y estética de la lectura», Literatura: teoría, historia, crítica, 7 (2005), pp. 69-86.

SERRANO SÁNCHEZ, Carmen, Los manuales epistolares en la España Moderna (siglos XVIXVII), Universidad de Alcalá: Departamento de Historia I y Filosofía, Alcalá, 2008, Trabajo de Suficiencia Investigativa inédito.

SIERRA MACARRÓN, «Escribir y leer para otros: figuras del analfabetismo en el texto cervantino», en A. Bernat Vistarini, ed., Volver a Cervantes, I, 2001, pp. 387-400.

SIERRA MACARRÓN, Leonor, «Analfabetos y cultura letrada en el siglo de Cervantes: los ejemplos del Quijote», Revista de Educación, número extraordinario: «El Quijote»y la educación, coord. Gabriel Janer Manila (2004), pp. 49-59.

Simón DíAZ, José, El libro antiguo español. Análisis de su estructura, Ollero y Ramos, Madrid, 2000.

Stalybrass, Peter; Chartier, Roger; Mowery, John Franklin y Wolfe, Heather, «Hamlet's Tables and the Technologies of Writing in Renaissance England», Shakespeare Quarterly, 55, 4 (2004), pp. 379-419.

TORNÉ, Emilio, «Arquitectura tipográfica del libro en el Siglo de Oro», en José M. Lucía Megías, ed., Imprenta, libros y lectura, 2006, pp. 243-273.

Torquemada, Antonio de, Manual de escribientes. Coloquios satíricos. Jardín de flores curiosas, en Obras completas, I, ed. y prólogo de Lina Rodríguez Cacho, TurnerBiblioteca Castro, Madrid, 1994.

Torres SAns, Xavier, Els llibres de família de pagès (segles XVI-XVIII). Memòries de pagès, memòries de mas, CCG Edicions, Gerona, 2000.

Vegas GonZÁlez, Serafín, El «Quijote» desde la reivindicación de la racionalidad, Centro de Estudios Cervantinos, Alcalá de Henares, 2006.

VIÑAO FraGO, Antonio, «Oralidad y escritura en el "Quijote": ¿Oposición o interacción?», Revista de Educación, número extraordinario: «El Quijote» y la educación, coord. Gabriel Janer Manila (2004), pp. 27-47.

WAQUET, Françoise, Parler comme un livre. L'oralité et le savoir $\left(X V I^{e}-X X^{e}\right.$ siècle), Albin Michel, París, 2003.

Wervaga Prieto, Ángel, Libros y lectura en Salamanca. Del Barroco a la Ilustración (16501725), Junta de Castilla y León: Consejería de Cultura y Turismo, Valladolid, 1993.

Wervaga Prieto, Ángel, Lectores y bibliotecas en la Salamanca moderna (1600-1789), Junta de Castilla y León: Consejería de Cultura y Turismo, 2008.

Recibido: 3 de febrero de 2011

Aceptado: 18 de julio de 2011 


\title{
Resumen
}

En el presente ensayo se aborda una aproximación a los usos y funciones de la cultura escrita en la España del Siglo de Oro tomando como referencia central las representaciones que del escrito se hacen en la obra de Cervantes, singularmente en el Quijote. Con tal propósito se han revisado el peso de la palabra hablada y escrita en la sociedad de aquel tiempo, las prácticas cotidianas de la escritura, los modos de difusión y recepción de los textos, el valor de la memoria, los efectos de la tipografía y, naturalmente, el sentido dado a la lectura y a las diversas maneras de efectuarse. Al final se incluye también una nota bibliográfica que inserta el universo cervantino en las coordenadas de la cultura escrita en la temprana Edad Moderna hispana.

Palabras clave: Escritura. Oralidad. Imprenta. Libro. Lectura. Memoria. Don Quijote. Cervantes. Siglo de Oro

Title: Mirrors of Ink. New Approaches to The Uses of Writing in Cervantes

\begin{abstract}
This essay offers an approach to studying the uses and functions of written culture in Golden Age Spain by taking as its central focus the representations of writing in the works of Cervantes, and above all his Don Qujote. It reviews the importance of the spoken and written word in early modern society, daily practices of writing, the means of diffusion and reception of texts, the significance of memory, the effects of printing and, of course, the diverse meanings and modes of reading. It closes with a bibliographic note which locates Cervantes' world in the context of early modern Spanish written culture.
\end{abstract}

Key words: Writing. Orality. Print. Book. Reading. Memory. Don Quijote. Cervantes. Golden Age. 